\title{
Nanosilver Incurs an Adaptive Shunt of Energy Metabolism Mode to Glycolysis in Tumor and Nontumor Cells
}

\author{
Yue Chen, ${ }^{+, \neq}$Zhe Wang, ${ }^{\dagger}$ Ming Xu, ${ }^{+}$Xiang Wang, ${ }^{\S}$ Rui Liu, ${ }^{\dagger}$ Qian Liu, ${ }^{+}$Zhihong Zhang, ${ }^{\ddagger}$ Tian Xia, ${ }^{\S}$ Jincai Zhao," \\ Guibin Jiang, ${ }^{\dagger}$ Yong $\mathrm{Xu}^{+,}{ }^{+, *}$ and Sijin Liu ${ }^{+, *}$ \\ ${ }^{\dagger}$ State Key Laboratory of Environmental Chemistry and Ecotoxicology, Research Center for Eco-Environmental Sciences, Chinese Academy of Sciences, Beijing \\ 100085, China, ${ }^{\ddagger}$ Department of Urology, The Second Hospital of Tianjin Medical University, Tianjin Institute of Urology, Tianjin 300211, China, ${ }^{\S}$ Division of \\ NanoMedicine, Department of Medicine, University of California, Los Angeles, California 90095, United States, and "Key Laboratory of Photochemistry, Beijing \\ National Laboratory for Molecular Sciences, Institute of Chemistry, Chinese Academy of Sciences, Beijing 100190, China
}

\begin{abstract}
Due to its significant antimicrobial properties, nanosilver $(\mathrm{nAg})$ has been substantially used in a wide spectrum of areas. This has raised the concerns on the detrimental effects on environment and human health. Although numerous studies have documented nAg-mediated toxicity to cells or organisms, little attempt has been made to study the biological impacts of $\mathrm{nAg}$ on cells at nontoxic concentrations, namely, the distinct biological effects that can be separated from direct cytotoxicity. Here, we studied nAg-mediated effects on energy metabolism in cells under sublethal exposure. Treatment of $\mathrm{nAg}$ at nontoxic concentrations resulted in a decline of ATP synthesis and attenuation of respiratory chain function in nontumor HEK293T cells and tumor cells with differential respiration rate,

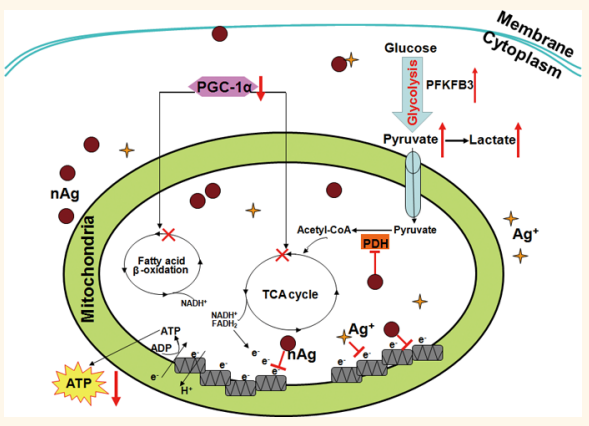
including HepG2, HeLa, A498, and PC3 cells. Cellular energy homeostasis was switched from oxidative phosphorylation-based aerobic metabolism to anaerobic glycolysis, which is an adaption process to satisfy the energy demand for cell survival. Nanospheres with smaller size showed greater capability to alter cellular energy metabolism than those with larger size or nanoplates. Mechanistic investigation manifested that inhibition of PGC-1 $\alpha$ by $n A g$ was, at least partially, accountable for the transition from oxidative phosphorylation to glycolysis. Additionally, altered expression of a few energy metabolismrelated genes (such as PFKFB3 and PDHA1) was also involved in the transition process. We further showed nAg-induced depolarization of mitochondrial membrane potential and reduction of respiratory chain complex activity. Together, our combined results uncovered the mechanisms by which nAg induced energy metabolism reprogramming in both tumor and nontumor cells under sublethal dosage.
\end{abstract}

KEYWORDS: silver nanoparticles · energy metabolism · oxidative phosphorylation · glycolysis $\cdot$ PGC-1 $\alpha$

$\mathrm{N}$ anomaterials are currently used in a wide range of products with more prospective applications; however, people raised concerns about their safety profiles. This is because nanomaterials have novel physicochemical properties that can interact with biological systems to generate toxicity. ${ }^{1}$ To date, most studies have focused on cytotoxicity of nanomaterials at high concentrations that incur significant injuries to cells in vitro and in animals; however, the high dosage used is often not realistic and fails to consider the potentially detrimental effects on human health under chronic lowdose exposure settings, such as everyday and environmental exposure. ${ }^{2}$ Thus, research is urgently needed to study the biological effects at sublethal or even nontoxic concentrations. Nanosilver ( $\mathrm{nAg}$ ), a material that is well-known for its antimicrobial properties, has been extensively used in a wide range of biomedical and consumer products. ${ }^{3-6}$ Although many studies have been performed to investigate the cytotoxicity of nAg under different settings, ${ }^{7-9}$ relatively little study has been conducted to understand the biological effects of $\mathrm{nAg}$ under nontoxic concentrations, which likely precede the toxicological processes or can be differentiated from cytotoxic effects but could perturb cellular homeostasis.

Under normal conditions, cells maintain a balanced energy homeostasis through concertedly regulated signaling and metabolic pathways. Namely, there is a perfect equilibrium between anabolism and catabolism

\section{* Address correspondence to sjliu@rcees.ac.cn, xuyong8816@sina.com.}

Received for review February 5, 2014 and accepted May 8, 2014.

Published online May 08, 2014 10.1021/nn500719m

(c) 2014 American Chemical Society 
through a never-ending cycle. ${ }^{10}$ However, disruptions of these pathways and signaling are likely associated with various disorders, such as fat accumulation. ${ }^{11,12}$ Moreover, maintaining the internal energy homeostasis will require cells and organisms to adapt (e.g., shift between different modes) in response to external stimuli; ${ }^{13-15}$ if they fail to do so, they may die. ${ }^{15}$ Mitochondria are the main organelle that is responsible for energy homeostasis in mammalian cells. ${ }^{16}$ Mitochondria govern energy production as the powerhouse of the cell; that is, mitochondria are best known to generate most adenosine triphosphate (ATP) used for energy-consuming biological processes. ${ }^{16}$ Mitochondrial dysfunctions or damage of mitochondrial integrity (such as membrane or genome) would lead to severe impairments to energy metabolism, causing many diseases including neurological disorders, myopathy, and diabetes. ${ }^{17}$ In addition, studies suggest that signaling transduction upon nanomaterial exposure could be integrated or amplified at the mitochondria, which can trigger oxidative stress and even cell death. ${ }^{18}$ However, to the best of our knowledge, no study has been conducted on $\mathrm{nAg}$-induced changes in cellular signaling transduction related to energy production, including the potential adaptive shunt of energy metabolism mode in cells in response to $\mathrm{nAg}$ exposure.

Energy production in normal somatic cells predominantly employs oxidative phosphorylation-based metabolism that occurs within active mitochondria, whereas tumor cells could simultaneously turn on glycolysis-based metabolism even in the presence of high concentration of oxygen (known as the "Warburg effect"). ${ }^{19}$ In this study, we aimed to scrutinize the impact of $n A g$ on cellular energy metabolism at sublethal concentrations. To evaluate this aspect, we used a panel of human cell lines, including nontumor human embryonic kidney cell line HEK293T and tumor cell lines with differential respiration rate ${ }^{20}$ that is, human cervical cancer cell line HeLa, human prostate cancer cell line PC3, human hepatic carcinoma cell line HepG2, and human renal carcinoma cell line A498. Respiration rate is a determinant of oxygen consumption coupled with $\mathrm{CO}_{2}$ production, which is indicative of the activity of mitochondrial oxidative phosphorylation. ${ }^{21,22}$ Figure 1 shows the design of this study. We uncovered that ATP production and the activity of mitochondrial respiratory chain were compromised for all cell lines upon sublethal nAg exposure. Cellular energy metabolism was changed from oxidative phosphorylation and fatty acid $\beta$-oxidation to glycolysis in nAg-treated cells. HEK293T cells were slightly more susceptible to this energy mode shift compared to tumor cells. Similar changes were found for $\mathrm{nAg}$ with different size or shape. Mechanistic studies revealed that downregulation of peroxisome proliferator-activated receptor $\gamma$ coactivator $1 \alpha$ (PGC-1 $\alpha$ ) is largely accountable for the

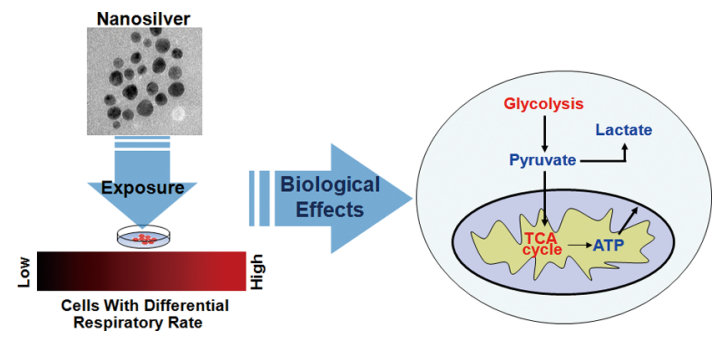

Figure 1. Schematic showing the primary design of the current study.

adaptive shunt in energy metabolism to glycolysis in response to $\mathrm{nAg}$ treatment. Meanwhile, adaptive gene expression of energy-related genes also contributed to energy mode transition. Additionally, $\mathrm{nAg}$ impaired mitochondrial membrane potential and electron transfer along the respiratory chain complexes. Together, this study identified a novel finding on $\mathrm{nAg}$-induced reprogramming of cellular energy metabolism.

\section{RESULTS AND DISCUSSION}

In the current work, we first chose to use silver nanospheres that have been demonstrated to have great bioavailability and biocompatibility to mammalian cells at low concentrations in our previous study. ${ }^{23}$ The transmission electron microscopy (TEM) imaging revealed that silver nanoparticles were spherical and homogeneously dispersed (Figure 2A), and the average diameter was $25 \mathrm{~nm}$, as evidenced by a histogram of measured size (Figure 2B). An absorption peak was observed around $400 \mathrm{~nm}$, as characterized by the absorption spectrum analysis (Figure 2C). Hydrodynamic diameter of $\mathrm{nAg}$ in complete culture medium (supplemented with $10 \%$ fetal bovine serum, FBS) was about $35 \mathrm{~nm}$, much smaller than that in water (approximately $76 \mathrm{~nm}$ ) (Figure 2D), indicating that $\mathrm{nAg}$ was well-dispersed in complete culture medium. The zeta-potential analysis revealed that $\mathrm{nAg}$ particles were negatively charged in both water and medium (Figure 2D). In order to study nAg-induced effects on energy metabolism, we deliberately endeavored to select the sublethal dosage that will not induce overt cytotoxicity. Therefore, we first surveyed cytotoxicity of all cell lines upon exposure to $\mathrm{nAg}$ by performing screening with a wide range of concentrations by Alamar Blue assay. Alamar Blue assay is designed to provide a rapid and sensitive measure of cytotoxicity, and it is a favorable and reliable approach to evaluate cytotoxicity of nanomaterials, especially for metal nanomaterials. ${ }^{24,25}$ As shown in Figure $3 \mathrm{~A}, \mathrm{nAg}$ at $10 \mu \mathrm{g} / \mathrm{mL}$ inhibited HEK293T cell growth by approximately $15 \%$ $(P<0.05)$, and the half-maximal inhibitory concentration (namely, $\mathrm{IC}_{50}$ ) was found around $30 \mu \mathrm{g} / \mathrm{mL}$ for HEK293T cells after $\mathrm{nAg}$ exposure for $24 \mathrm{~h}(P<0.05)$. Conversely, $\mathrm{nAg}$ with concentrations less than $10 \mu \mathrm{g} / \mathrm{mL}$ (such as at 2,4 , and $8 \mu \mathrm{g} / \mathrm{mL}$ ) did not cause cytotoxicity up to $24 \mathrm{~h}$ (Figure $3 \mathrm{a}, P>0.05$ ), and there was only a 


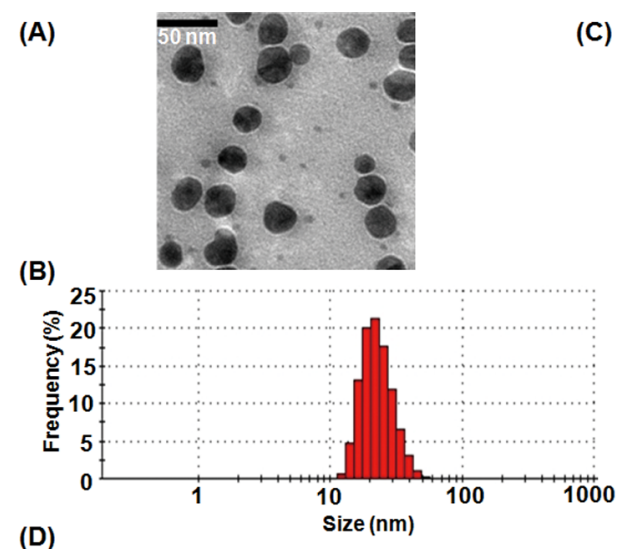

(C)

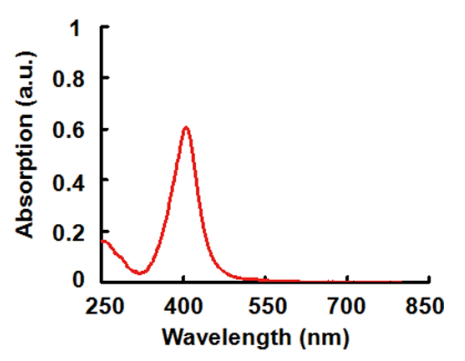

(D)

\begin{tabular}{ccccc}
\hline \multirow{2}{*}{$\mathrm{nAg}$} & \multicolumn{2}{c}{ Hydrodynamic diameter $(\mathrm{nm})$} & \multicolumn{2}{c}{ Zeta potential $(\mathrm{mV})$} \\
& Water & Medium & Water & Medium \\
\hline $8 \mu \mathrm{g} / \mathrm{ml}$ & $76.65 \pm 5.73$ & $35.2 \pm 1.21$ & $-4.76 \pm 0.19$ & $-3.6 \pm 0.27$ \\
\hline
\end{tabular}

Figure 2. Characterization of $25 \mathrm{~nm}$ silver nanoparticles. (A) Representative TEM image of $\mathrm{nAg}$ used in the current study. The scale bar is $50 \mathrm{~nm}$, and the original magnification is $\times \mathbf{4 0 0 0 0 0}$. (B) Particle size distribution of $\mathrm{nAg}$. (C) UV-visible absorption spectra of $\mathrm{nAg}$. The maximum of absorbance is at $400 \mathrm{~nm}$. (D) Hydrodynamic diameter and zeta-potentials of $\mathrm{nAg}$ at $8 \mu \mathrm{g} / \mathrm{mL}$ in water and complete culture medium.

(A)
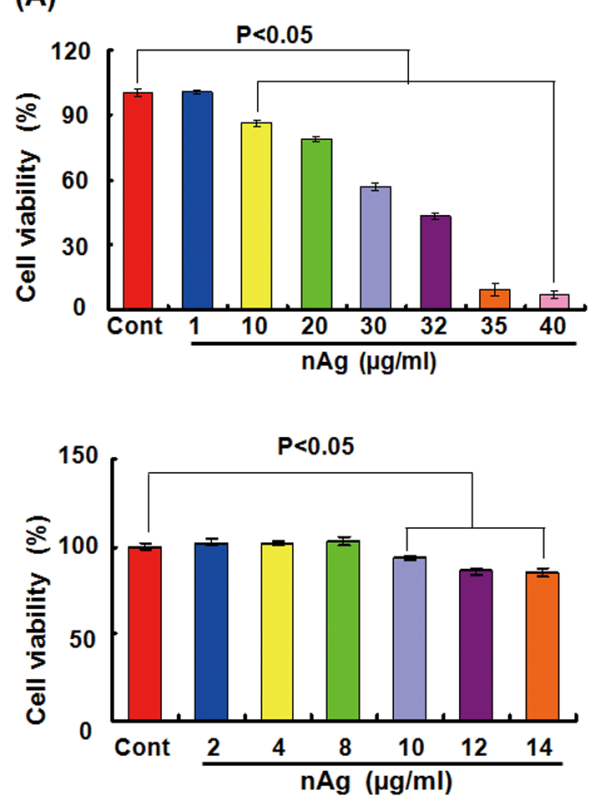

(B)

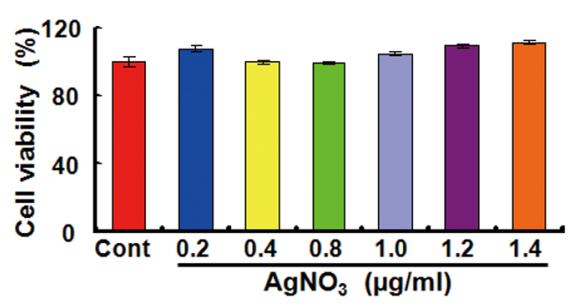

(C)

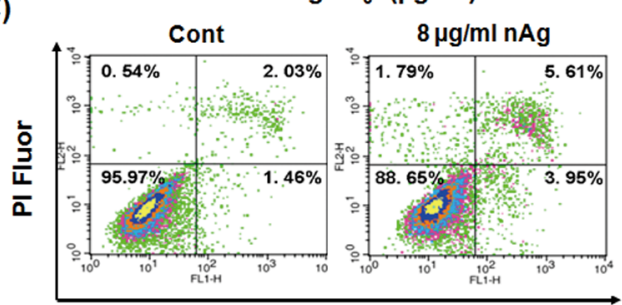

(D)

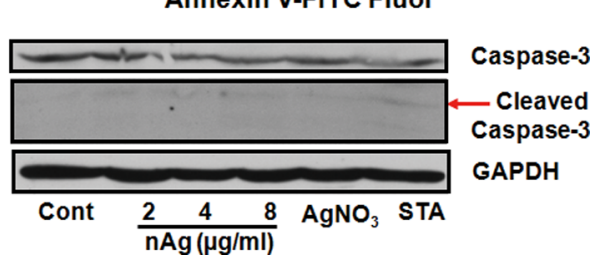

Figure 3. Cytotoxicity evaluation and apoptosis detection upon nAg exposure in HEK293T cells. (A) Cytotoxicity was determined through the Alamar Blue assay in HEK293T cells upon exposure to $\mathrm{nAg}$ at various concentrations for $24 \mathrm{~h}(n=6)$. (B) Cytotoxicity was assessed with the Alamar Blue assay in HEK293T cells treated with Ag ions at different concentrations for $24 \mathrm{~h}(n=6)$. (C) Representative FACS scatter plots of apoptosis for cells treated with $8 \mu \mathrm{g} / \mathrm{mL} \mathrm{nAg}$ relative to untreated cells using Annexin-V FITC and PI staining. Experiments were performed in biological triplicate $(n=3)$. (D) Western blot analysis of caspase-3 activation in HEK293T cells upon exposure to $\mathrm{nAg}$ or $0.8 \mu \mathrm{g} / \mathrm{mL} \mathrm{AgNO}$ for $24 \mathrm{~h}$. Staurosporine was used as a positive control to activate cleavage of caspase-3. The red arrow indicates cleaved caspase-3.

slight decline of cell viability after $48 \mathrm{~h}$ exposure (Supporting Information Figure S1). Therefore, we selected sublethal $\mathrm{nAg}$ concentrations $(2-8 \mu \mathrm{g} / \mathrm{mL})$ to study the biological effects in HEK293T cells that showed minimal cytotoxicity. It is known that silver nanoparticles could release $\mathrm{Ag}$ ions that predominantly (if not completely) account for the toxicity of $\mathrm{nAg}$ to cells and microorganisms. ${ }^{9,26,27}$ We thus also evaluated the possible cytotoxicity of Ag ions dissolved from nAg to HEK293T cells. By assessing the rate of Ag ion dissolution from $\mathrm{nAg}$ in culture medium, we found that $9.3 \%$ of $\mathrm{Ag}$ could be dissolved into $\mathrm{Ag}^{+}$from $\mathrm{nAg}$, which is consistent with our previous result of $<10 \%$ dissolution of silver nanoparticles. ${ }^{23}$ As shown in Figure $3 \mathrm{~B}, \mathrm{Ag}$ ions did not impair cell growth the maximal rate of dissolution (i.e., $0.8 \mu \mathrm{g} / \mathrm{mL}$ ) and even at 
(A)

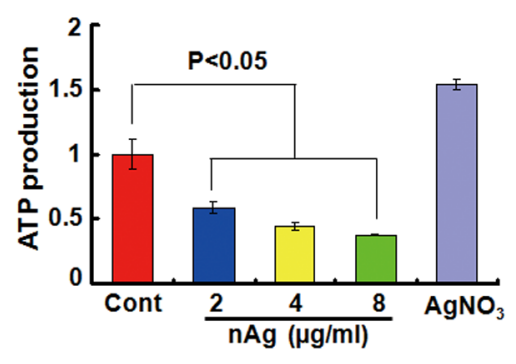

(B)

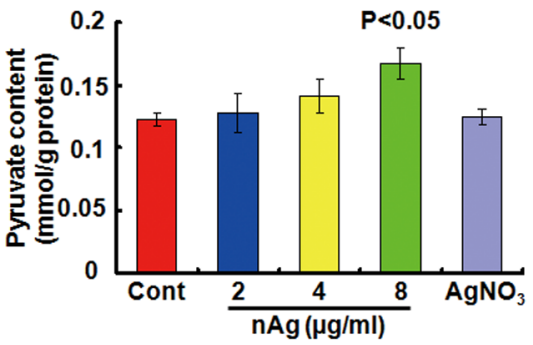

(C)

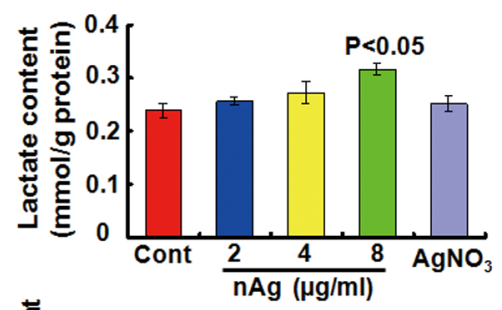

(D)

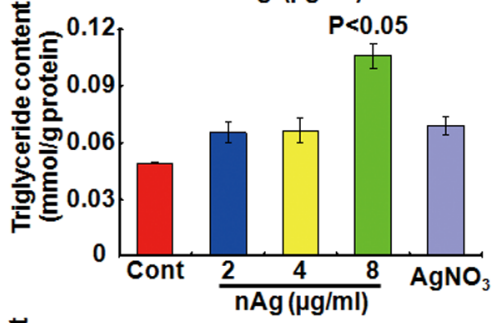

(E)

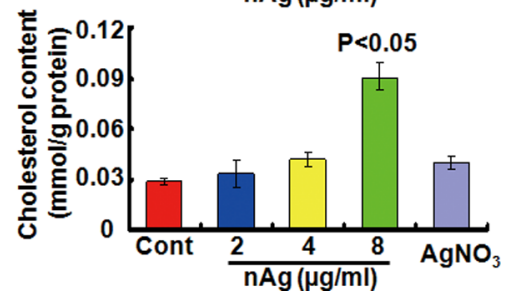

Figure 4. Cellular energy metabolism in HEK293T cells in response to $\mathrm{nAg}$ treatment. (A) Relative cellular ATP levels in cells upon $\mathrm{nAg}$ or $\mathrm{Ag}^{+}$treatment for $\mathbf{2 4} \mathrm{h}$. Bioluminescent intensity reflecting cellular ATP concentration was assayed with a microplate reader $(n=4)$. The levels of pyruvate (B), lactate (C), triglyceride (D), and cholesterol (E) in HEK293T cells treated with $\mathrm{nAg}$ or $\mathrm{AgNO}_{3}$ for $24 \mathrm{~h}(n=3-4)$. The concentration for $\mathrm{AgNO}_{3}$ is $0.8 \mu \mathrm{g} / \mathrm{mL}$.

a dose greater than $0.8 \mu \mathrm{g} / \mathrm{mL}$, such as $1.4 \mu \mathrm{g} / \mathrm{mL}(P>$ $0.05)$. These results suggested that $\mathrm{nAg}$ did not elicit toxicity to HEK293T cells at the concentrations used in the current study, even after taking into consideration released $\mathrm{Ag}$ ions. To confirm this finding, we evaluated apoptosis of HEK293T cells upon $8 \mu \mathrm{g} / \mathrm{mL} \mathrm{nAg}$ using Annexin V-FITC (fluorescein isothiocyanate) and PI (propidium iodide) staining with flow cytometry (FACS) analysis. As shown in Figure 3C, there was only a marginal increase of apoptotic cells upon $\mathrm{nAg}$ treatment at $8 \mu \mathrm{g} / \mathrm{mL}$ for $24 \mathrm{~h}$ compared to untreated cells ( $2.0 \%$ vs $5.6 \%$ for Annexin $\mathrm{V}^{+} \mathrm{PI}^{+}$cells), which is consistent with the results of cytotoxicity assessment (Figure 3A). However, significantly greater cell death was induced when cells were treated with $\mathrm{nAg}$ at $20 \mu \mathrm{g} / \mathrm{mL}$ (Figure S2), in agreement with the results of cytotoxicity assay (Figure 3A). Moreover, Ag ions at $0.8 \mu \mathrm{g} / \mathrm{mL}$ did not induce cell death for HEK293T cells (Figure S3), also in parallel to the cytotoxicity results (Figure 3B). Activation of caspase-3 is a key event during the late stage of apoptosis and cleaved caspase-3, a central effector of caspase family, initiates the programmed cell death. ${ }^{28}$ We assessed both fulllength caspase- 3 and cleaved caspase- 3 in nAg-treated cells through Western blot analysis. Staurosporine, a positive control, was used to induce activation of caspase- 3 as manifested by an increase of cleaved caspase-3 (Figure 3D). In support of a little induction of apoptosis as discussed above, we found that indeed low concentrations of $\mathrm{nAg}$ induced only a slight increase in cleaved caspase-3, and the concentration of cleaved caspase- 3 in cells treated with $8 \mu \mathrm{g} / \mathrm{mL} \mathrm{nAg}$ was slightly higher than that in cells treated with 2 and $4 \mu \mathrm{g} / \mathrm{mL} \mathrm{nAg}$ (Figure 3D). Meantime, $0.8 \mu \mathrm{g} / \mathrm{mL} \mathrm{\textrm {ANO } _ { 3 }}$ induced little increase of cleaved caspase-3, supporting the finding of no induction of apoptosis by Ag ions. Using the same approach, we screened cytotoxicity of nAg to HepG2, HeLa, A498, and PC3 cells, and similar sublethal concentrations $(2-8 \mu \mathrm{g} / \mathrm{mL}$ ) were identified for these cell lines (Figure S4). Previous studies have demonstrated that $\mathrm{nAg}$ has substantial capability to cross cellular membrane and biological barriers, whereas $\mathrm{Ag}$ ions have very limited ability to reach inside cells. ${ }^{23,29,30}$ It is thus reasonable to assume that $\mathrm{nAg}$ could elicit distinct biological effects once inside cells, irrespective of released $\mathrm{Ag}$ ions outside of cells. These results together indicated that no significant cytotoxicity was incurred to HEK293T, HepG2, HeLa, A498, and PC3 cells by nAg at sublethal concentrations, which was independent of $\mathrm{nAg}$ dissolution. Nonetheless, it is still possible that $\mathrm{nAg}$ could induce other biological effects on cells which have not been recognized yet but warrant future investigation. We here embarked on potential effects of $\mathrm{nAg}$ at low concentrations on cellular energy metabolism.

To evaluate the possible changes in energy state of cells, we measured cellular ATP levels after nAg exposure. As indicated in Figure 4A, ATP levels were reduced approximately by 40,55 ,and $60 \%$ in HEK293T cells incubated with $\mathrm{nAg}$ treatment for $24 \mathrm{~h}$ at 2,4 , and $8 \mu \mathrm{g} / \mathrm{mL}$, respectively, compared to control $(P<0.05)$. In contrast, $0.8 \mu \mathrm{g} / \mathrm{mL} \mathrm{Ag}$ ions induced slightly 
increased cellular ATP synthesis. Consistent with our results, other types of nanomaterials such as zinc oxide and silicon nanoparticles were also reported to inhibit the ATP production, ${ }^{31-33}$ devoid of clear molecular mechanisms. Since oxidative phosphorylation is the predominant source of energy in differentiated cells, ${ }^{34}$ we postulate that $\mathrm{nAg}$ treatment could inhibit oxidative phosphorylation. To validate this hypothesis, we examined the activities of oxidative phosphorylation including glucose and lipid metabolism in cells upon nAg exposure. As shown in Figure 4B, pyruvate content was increased by $15 \%$ in HEK293T cells treated with $4 \mu \mathrm{g} / \mathrm{mL} \mathrm{nAg}$ for $24 \mathrm{~h}$, and $>35 \%$ increase was found in cells upon $8 \mu \mathrm{g} / \mathrm{mL} \mathrm{nAg}$, in comparison with untreated cells $(P<0.05)$. Similarly, lactate concentration was also increased in nAg-treated cells, especially about 35\% increase at $8 \mu \mathrm{g} / \mathrm{mL}(P<0.05)$ compared to the control (Figure $4 \mathrm{C}$ ). Ag ions at $0.8 \mu \mathrm{g} / \mathrm{mL}$ had little effect on pyruvate and lactate levels (Figure $4 B, C$ ). These results suggested that glycolysis was enhanced in HEK293T cells in response to $\mathrm{nAg}$. Glycolysis is performed in the cytoplasm, whereas oxidation of lipid (mostly through $\beta$-oxidation) occurs in mitochondria. We then assessed the levels of triglyceride and cholesterol in HEK293T cells upon $\mathrm{nAg}$ exposure. The triglyceride level was increased by about $30 \%$ in cells upon $\mathrm{nAg}$ treatment at 2 and $4 \mu \mathrm{g} / \mathrm{mL}$ for $24 \mathrm{~h}$ and was further increased by more than 2 -fold in cells treated with $8 \mu \mathrm{g} / \mathrm{mL}$ compared to the control (Figure 4D, $P<0.05$ ). Similar to the increase of triglyceride, there was also nearly 3-fold increase of cholesterol content in $8 \mu \mathrm{g} / \mathrm{mL}$ exposed cells compared to untreated cells (Figure $4 \mathrm{E}, P<0.05$ ). Ag ions did not significantly alter the concentrations of triglyceride and cholesterol compared to $\mathrm{nAg}$ treatment (Figure 4D,E). These results revealed that $\mathrm{nAg}$ hampered oxidative phosphorylation and lipid metabolism in mitochondria, and to compensate for the energy shortage, nAg concurrently switched on glycolysis in HEK293T cells. Most strikingly, we found rather similar changes in all tumor cells upon $\mathrm{nAg}$ treatment at sublethal concentrations (Figure 5). There was a significant decline in ATP production associated with an increase of pyruvate and lactate concentrations and simultaneous intracellular triglyceride and cholesterol accumulation in nAg-treated HepG2, HeLa, A498,and PC3 cells compared to untreated cells or Ag ion-treated cells (Figure 5). In short, we identified a significant shunt of energy metabolism mode to glycolysis in tumor and nontumor cells with distinct respiration rate upon treatment with sublethal nAg. HEK293 cells are originally derived from human embryonic kidney cells. These cells are not tumor cells per se and not malignant and, in fact, are widely used as nontumor cells in a wide spectrum of research fields. When compared to tumor cells, HEK293T cells appeared to be more susceptible to $\mathrm{nAg}$-induced energy mode shift, underpinning the differences in energy

\begin{tabular}{|c|c|c|c|c|}
\hline \multirow{2}{*}{ Determinant } & \multirow{2}{*}{ Cell } & \multicolumn{3}{|c|}{ Nanoparticles $(\mu \mathrm{g} / \mathrm{ml})$} \\
\hline & & 2 & 4 & $6^{a}$ or $8^{b}$ \\
\hline \multirow{5}{*}{ ATP } & 293T & $\downarrow \downarrow$ & $\downarrow \downarrow \downarrow$ & $\downarrow \downarrow \downarrow \downarrow$ \\
\hline & A498 & - & $\downarrow$ & $\downarrow \downarrow$ \\
\hline & HeLa & - & $\downarrow$ & $\downarrow \downarrow$ \\
\hline & HepG2 & $\downarrow$ & $\downarrow$ & $\downarrow \downarrow$ \\
\hline & PC3 & - & $\downarrow$ & $\downarrow \downarrow$ \\
\hline \multirow{5}{*}{ Lactate } & 293T & - & $\boldsymbol{\uparrow}$ & $\uparrow \uparrow$ \\
\hline & A498 & - & $\uparrow$ & $\uparrow \uparrow$ \\
\hline & HeLa & - & $\mathbf{t}$ & $\uparrow \uparrow$ \\
\hline & HepG2 & $\uparrow$ & $\uparrow$ & $\uparrow \uparrow$ \\
\hline & PC3 & $\uparrow \uparrow$ & $\uparrow \uparrow$ & $\uparrow \uparrow \uparrow$ \\
\hline \multirow{5}{*}{ Pyruvate } & 293T & - & $\uparrow$ & $\uparrow \uparrow$ \\
\hline & A498 & - & $\uparrow$ & $\uparrow \uparrow$ \\
\hline & HeLa & - & $\uparrow$ & $\uparrow \uparrow$ \\
\hline & HepG2 & - & $\uparrow$ & $\uparrow$ \\
\hline & PC3 & $\uparrow$ & 41 & $\uparrow \uparrow \uparrow$ \\
\hline \multirow{5}{*}{ Triglyceride } & $293 \mathrm{~T}$ & $\uparrow \uparrow$ & 41 & $\uparrow \uparrow \uparrow \uparrow$ \\
\hline & A498 & $\uparrow$ & $\uparrow t$ & $\uparrow \uparrow$ \\
\hline & HeLa & - & $\uparrow$ & $\uparrow \uparrow \uparrow \uparrow$ \\
\hline & HepG2 & 一 & $\uparrow$ & $1 \uparrow \uparrow$ \\
\hline & PC3 & - & $\uparrow$ & $\uparrow \uparrow$ \\
\hline \multirow{5}{*}{ Cholesterol } & $293 T$ & $\uparrow$ & $\uparrow \uparrow \uparrow$ & $\uparrow \uparrow \uparrow \uparrow$ \\
\hline & A498 & $\uparrow$ & $\uparrow \uparrow$ & $\uparrow \uparrow \uparrow$ \\
\hline & HeLa & - & $\uparrow$ & $\uparrow \uparrow$ \\
\hline & HepG2 & - & $\uparrow$ & 44 \\
\hline & PC3 & - & $\mathbf{T}$ & $\uparrow \uparrow$ \\
\hline
\end{tabular}

Figure 5. Influence of nAg on cellular energy metabolism in various cells. Relative changes of ATP, pyruvate, lactate, triglyceride, and cholesterol to the control were shown in arrows after cells were treated with $\mathrm{nAg}$ at different concentrations for $24 \mathrm{~h}(n=3-4)$. Arrows represent increase or decrease in content, as 1 arrow, $\sim 20 \%$; 2 arrows, $\sim 40 \% ; 3$ arrows, $\sim 60 \%$; and 4 arrows, $>60 \%$. Dash $(-)$ indicates no significant change. Letter (a) refers to PC3 cells, and letter (b) indicates HEK293T, HeLa, HepG2, and A498 cells.

metabolism mode between tumor cells (oxidative phosphorylation plus glycolysis) and nontumor cells (predominantly oxidative phosphorylation). ${ }^{20}$

Since $n A g$ could be engulfed by cells through endocytosis and nanospheres have enforced bioavailability in cells relative to nanoparticles with other shapes, $^{35-37}$ to see if these findings could be expanded to $\mathrm{nAg}$ with different size and shape, we included 20 and $40 \mathrm{~nm}$ spherical $\mathrm{nAg}$ and $45 \mathrm{~nm}$ plate-like $\mathrm{nAg}$ with same surface coating as $25 \mathrm{~nm}$ sphere-like $\mathrm{nAg}$ used above (Figure 6A). We also used sublethal concentrations in cell exposure for these nanomaterials after surveying their cytotoxicity (Figure S5). Consistent with the results with $25 \mathrm{~nm} \mathrm{nAg}, 20$ and $40 \mathrm{~nm}$ spherical $\mathrm{nAg}$ and $45 \mathrm{~nm}$ plate-like $\mathrm{nAg}$ could similarly alter cellular energy metabolism, as manifested by reduced ATP, increased pyruvate and lactate content, and intracellular triglyceride and cholesterol accumulation (Figure 6B). Among these $\mathrm{nAg}$ particles with different size and shape, 20 and $25 \mathrm{~nm}$ nanospheres exhibited a greater ability to alter cellular energy metabolism than $40 \mathrm{~nm}$ nanospheres and $45 \mathrm{~nm}$ nanoplates, especially at 2 and $4 \mu \mathrm{g} / \mathrm{mL}$. It is a reminder that smaller $\mathrm{nAg}$ particles might be more prone to enter into cells. ${ }^{35-37}$ In agreement with these results, we recently demonstrated that $\mathrm{nAg}$ particles with smaller size showed greater effects on inhibiting globin expression in erythroid cells than those with larger size, and $\mathrm{nAg}$ particles with spherical shape 
(A)

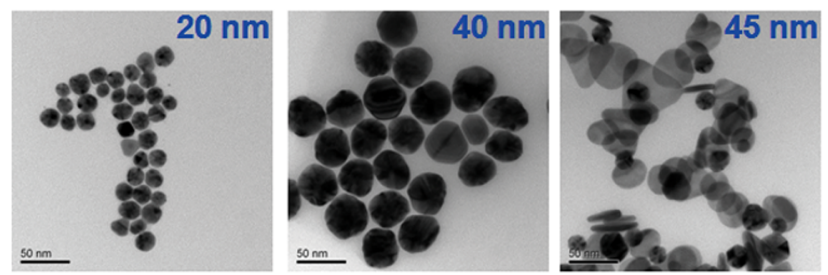

(B)

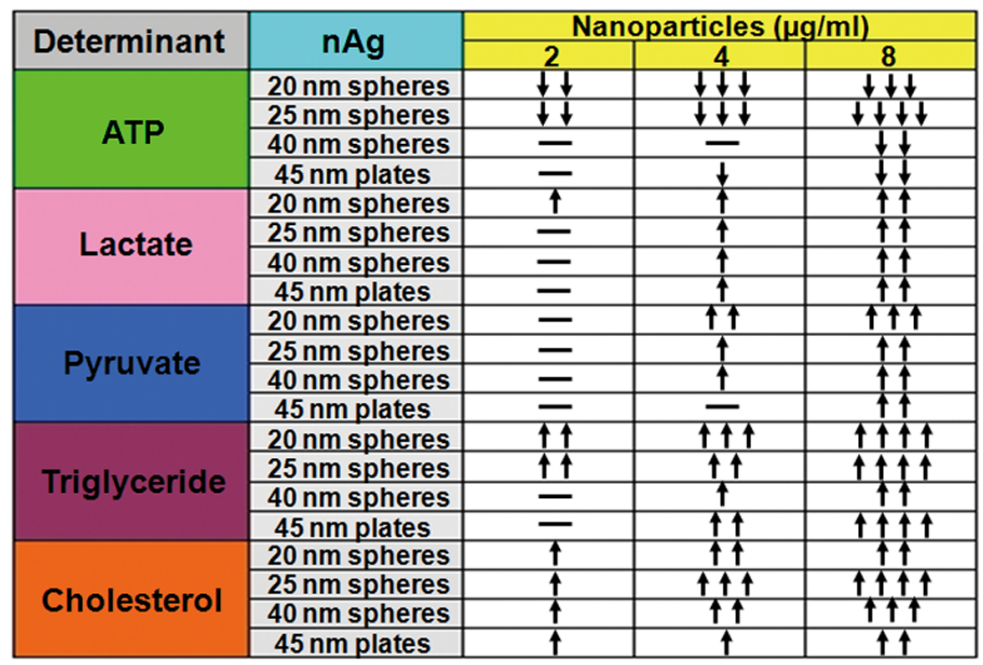

Figure 6. Alterations of energy metabolism upon $\mathrm{nAg}$ with distinct size and shape. (A) Representative TEM images of $\mathrm{nAg}$ with different size and shape. The scale bar is $50 \mathrm{~nm}$, and the original magnification is $\times \mathbf{4 0 0 0 0 0}$. (B) Determination of energy metabolism reflected by the relative alterations of ATP, pyruvate, lactate, triglyceride, and cholesterol to the control after HEK293T cells were treated with nAg at different concentrations for $24 \mathrm{~h}(n=3-4)$. Arrows represent increase or decrease in content, as 1 arrow, 20\%; 2 arrows, $\sim 40 \% ; 3$ arrows, $\sim 60 \%$; and 4 arrows, $>60 \%$. Dash (一) indicates no significant change.

revealed enhanced capability to suppress globin expression compared to those in plate shape. ${ }^{23}$

We next studied the molecular bases underlying the energy mode change in response to $\mathrm{nAg}$. Since smallsized $\mathrm{nAg}$ showed greater effects on driving energy mode shift than those with larger size or in plate shape and HEK293T appeared to be more sensitive to nAgconducted energy mode change as discussed above, we embarked on the molecular mechanisms using HEK293T cells and $25 \mathrm{~nm}$ sphere-like $\mathrm{nAg}$ in the following experiments. PGC- $1 \alpha$, a transcriptional coactivator, essentially orchestrates energy metabolism in a concerted way by interacting with and modulating the basal transcriptional machinery of most nuclear receptors and a few transcriptional factors that are energyrelated. ${ }^{38}$ PGC- $1 \alpha$ translocates from cytoplasm into the nucleus upon energy status alterations, which in turn reprograms energy metabolism by promoting expression of nuclear-encoded mitochondrial proteins. ${ }^{38}$ Previous studies have shown that PGC- $1 \alpha$ regulates fundamental metabolic pathways, including fatty acid oxidation, ${ }^{39}$ mitochondrial oxidative phosphorylation, ${ }^{40}$ gluconeogenesis, ${ }^{41}$ and ROS metabolism. ${ }^{42}$ For example, PGC- $1 \alpha$ is activated to promote expression of genes involved in gluconeogenesis and fatty acid oxidation in hepatocytes upon fasting. ${ }^{41,43}$ Similarly, forced expression of PGC- $1 \alpha$ in muscle robustly enhances mitochondrial biogenesis, coupled to a shunt of energy dependence on fatty acids. ${ }^{43,44}$ Additionally, PGC- $1 \alpha$ also modulates cholesterol metabolism by serving as a coactivator of $L X R \alpha$ (liver $X$ receptor alpha) and activating Cyp7A1 (cholesterol 7alpha-hydroxylase) expression. ${ }^{45-47}$ Therefore, $\mathrm{PGC}-1 \alpha$ is recognized as the central regulator of mitochondrial energy transduction. However, whether nAg could exert effects on PGC- $1 \alpha$ remains unexplored. We then examined the influence of $\mathrm{nAg}$ treatment on PGC- $1 \alpha$ concentration. The qRT-PCR analysis revealed a dose-dependent decrease of PGC- $1 \alpha$ mRNA level in cells treated with $\mathrm{nAg}$ at 2,4 , and $8 \mu \mathrm{g} / \mathrm{mL}$ for $24 \mathrm{~h}$ compared to control cells $(P<0.05)$, and $\mathrm{nAg}$ at $8 \mu \mathrm{g} / \mathrm{mL}$ showed the greatest inhibition on PGC-1 $\alpha$ expression with about $45 \%$ decline compared to the control (Figure 7A, $P<0.05$ ). Similar to the alteration of the mRNA level, the protein concentration of PGC- $1 \alpha$ was also greatly diminished in cells after $n A g$ exposure for $24 \mathrm{~h}$, compared with the control (Figure 7B). The reduction of PGC- $1 \alpha$ is consistent with the accumulation of triglyceride and cholesterol in nAg-treated cells as described in Figure 5. We further surveyed the adaptive responses of PGC-1 $\alpha$ target genes involved in oxidative phosphorylation and fatty acid oxidation. The qRT-PCR results revealed a significant decline of mRNA levels of oxidative phosphorylation-related genes including COX7B (cytochrome $c$ oxidase subunit VIIb), SDHA (succinate dehydrogenase complex $A$ ), UQCRC1 (ubiqinolcytochrome $c$ reductase core protein), and ATP5O 
(A)

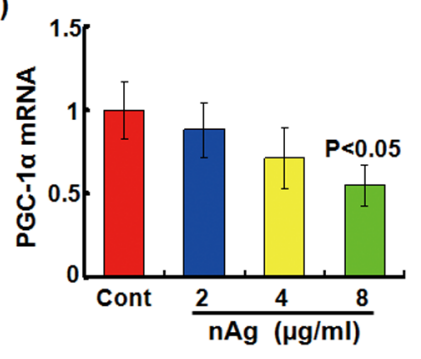

(B)

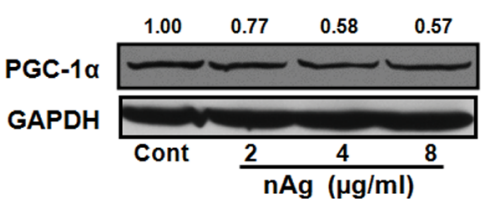

(D)

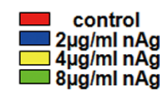

$\begin{gathered}\text { control } \\ 2 \mu \mathrm{g} / \mathrm{ml} \mathrm{nAg} \\ 4 \mu \mathrm{m} / \mathrm{ml} \mathrm{nAg}\end{gathered}$
$8 \mu \mathrm{g} / \mathrm{ml} \mathrm{nAg}$

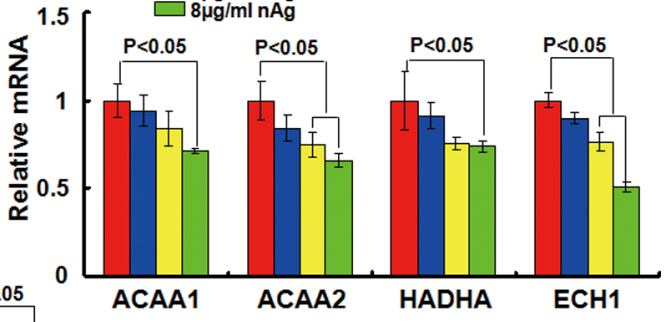

(C)

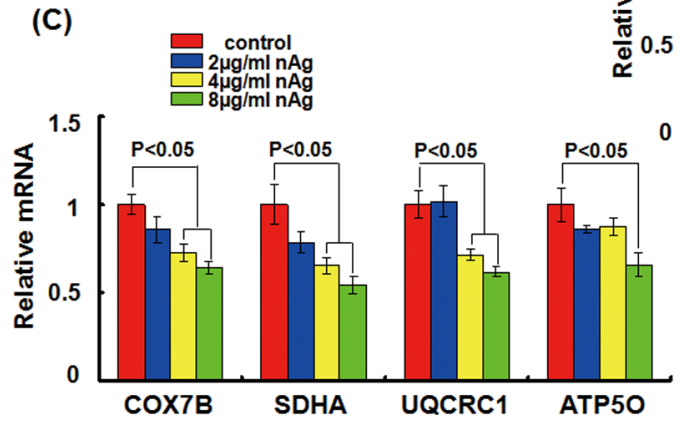

Figure 7. Levels of PGC-1 $\alpha$ and its targets upon $n A g$ exposure. (A) qRT-PCR analysis of PGC-1 $\alpha$ expression in HEK293T cells exposed to $\mathrm{nAg}$ for $24 \mathrm{~h}(n=4)$. (B) PGC-1 $\alpha$ protein levels in HEK293T cells after treatment with $\mathrm{nAg}$ for $24 \mathrm{~h}$. (C) Expression changes of genes involved in oxidative phosphorylation in HEK293T cells exposed to $\mathrm{nAg}$ for $24 \mathrm{~h}$, as characterized by qRTPCR analysis $(n=4)$. (D) Alterations of genes related to fatty acid oxidation in HEK293T cells after $24 \mathrm{~h}$ treatment, as reflected by qRT-PCR analysis $(n=4)$.

(ATP synthase, $\mathrm{O}$ subunit) in $\mathrm{nAg}$-treated cells at 4 and $8 \mu \mathrm{g} / \mathrm{mL}$ compared to the control, particularly at $8 \mu \mathrm{g} / \mathrm{mL}$ nAg (Figure 7C, $P<0.05$ ). Further qRT-PCR analysis indicated that nontoxic $\mathrm{nAg}$ also reduced the mRNA levels of genes involved in fatty acid oxidation in a dosedependent manner, including ACAA1 (acetyl-CoA acyltransferase 1), ACAA2 (acetyl-CoA acyltransferase 2), HADHA (hydroxyacyl-CoA dehydrogenase), and ECH1 (enoyl-coenzyme A hydratase 1) (Figure 7D, $P<0.05$ ). These results suggested that $\mathrm{nAg}$ exposure compromised oxidative phosphorylation and fatty acid oxidation through robust inhibition of PGC- $1 \alpha$ and PGC- $1 \alpha$ target genes.

PFKFB3 (phosphofructokinase-2/fructose-2,6-bisphosphatase), a strong activator in glycolysis, has higher kinase activity than other PFKFB isoenzymes. ${ }^{48}$ It synthesizes fructose-2,6-bisphosphate and serves as an allosteric activator of 6-phosphofructo-1-kinase, a rate-limiting enzyme of glycolysis. Considering enhanced glycolysis upon $\mathrm{nAg}$ treatment, we determined the mRNA level of PFKFB3 in nAg-treated cells. The level of PFKFB3 mRNA was greatly increased by more than 3.5 -fold in $\mathrm{nAg}$-treated cells at $8 \mu \mathrm{g} / \mathrm{mL}$, relative to untreated cells (Figure $8 \mathrm{~A}, P<0.05$ ). The induction of PFKFB3 by $n A g$ treatment is presumably secondary to the deficit in energy supply in nAg-treated cells, which agrees with an adaptive mechanism that switches on glycolysis to meet energy demand. ${ }^{49}$ Similar to our finding, PFKFB3 has been shown to be induced to enhance glycolysis in order to compensate energy shortage in cancer cells. ${ }^{48}$ In addition, we also looked
(A)

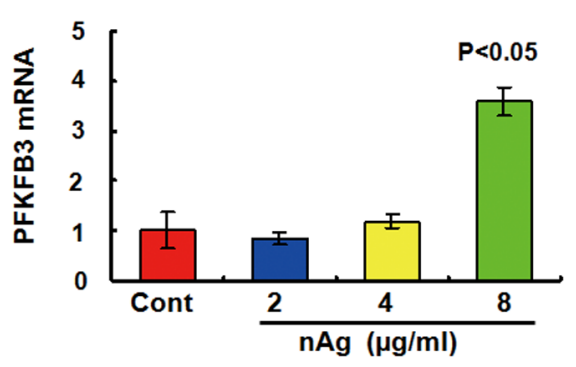

(B)

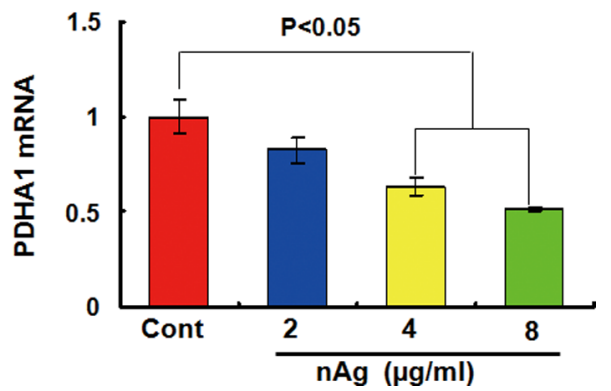

Figure 8. Gene expression related to glycolysis and TCA upon treatment with $\mathrm{nAg}$. Relative levels of (A) PFKFB3 and (B) PDHA1 mRNAs in HEK293T cells upon $n A g$ for $24 \mathrm{~h}$, as determined by qRT-PCR $(n=4)$.

into the changes of pyruvate dehydrogenase (PDH), a key enzyme that catalyzes pyruvate to acetyl-coenzyme $A .{ }^{50}$ As shown in Figure 8B, the mRNA expression of PDHA1 was decreased by $\mathrm{nAg}$ treatment, especially in cells treated with 4 and $8 \mu \mathrm{g} / \mathrm{mL} \mathrm{nAg}$, compared with untreated cells $(P<0.05)$. The detailed mechanism responsible for $\mathrm{nAg}$-mediated inhibition of $\mathrm{PDHA} 1$ 
needs further investigation. Nevertheless, this finding suggested that $\mathrm{PDH}$ reduction certainly contributed to the overall inhibition of oxidative phosphorylation by $\mathrm{nAg}$, in parallel to its crucial role in initiating tricarboxylic acid cycle (TCA) and oxidative phosphorylation. ${ }^{51-53}$

Mitochondria are the main factory of cellular ATP production in mammalian cells through oxidation of glucose and fatty acids. Electron transfer via redox reactions yields proton gradient across the mitochondrial inner membrane, which subsequently drives ATP synthesis. Dysfunction or perturbation of electron transfer or redox reactions would reduce ATP production and render cells to reprogram energy metabolism. Given the results of ATP reduction and attenuation of oxidative phosphorylation upon $\mathrm{nAg}$ as described above, we postulated that there could be direct impairment of mitochondria-centered energy transduction. We thereafter looked into nAg's intracellular localization, mitochondrial membrane potential and respiratory chain complex activity. Significant mass of $\mathrm{nAg}$ was found inside cells through TEM (Figure 9), similar to previous results. ${ }^{54}$ It is possible that the intracellular presence of $\mathrm{nAg}$ would directly or indirectly affect mitochondria, as reported by a previous study. ${ }^{36}$ Nonetheless, there is still a lack of evidence demonstrating the association between biological effects and Ag's direct mitochondrial perturbation. A recent study on patients with burns showed that fibroblasts deep under burned skin could have nAg uptake released from Acticoat (a nanocrystalline silver dressing), and $\mathrm{nAg}$ was located close to the outer membrane of mitochondria. ${ }^{55}$ Mitochondrial disruption includes reduction of the membrane potential and subsequent disorders of the oxidation-reduction system linked to energy metabolism. To this end, we closely looked at alterations of mitochondrial membrane potential. 5,5',6,6'-Tetrachloro-1,1',3,3'-tetraethylbenzimidalyl carbocyanine iodide (JC-1) dye is used to selectively stain mitochondria as an indicator of mitochondrial membrane potential. ${ }^{56,57} \mathrm{JC}-1$ exists in two different forms inside mitochondria. When the membrane potential is high, JC- 1 is in aggregated form emitting red fluorescence, and when membrane potential dissipates, JC-1 in monomer form emitting green fluorescence, reflecting depolarized membrane potential. In other words, JC-1 forms complexes known as J-aggregates showing red fluorescence in intact mitochondria with high potential, whereas JC-1 tends to retain a monomeric form displaying the original green fluorescence in unhealthy or wounded mitochondria with low potential. Accordingly, the transition of fluorescence from red to green (i.e., increased green to red fluorescence) indicates a decrease of mitochondrial membrane potential. ${ }^{58}$ We assessed these two colors in cells upon $\mathrm{nAg}$ through confocal microscopy. As shown in Figure 10A, an increase of green fluorescence (the top panel) was induced in cells treated with

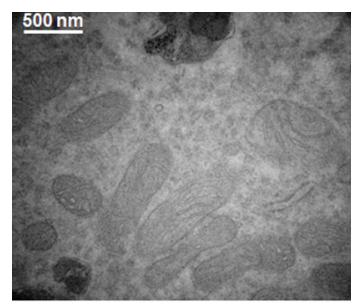

Control

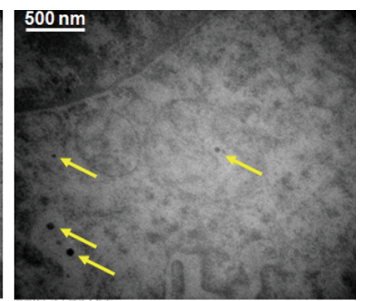

$8 \mu \mathrm{g} / \mathrm{mL} \mathrm{nAg}$
Figure 9. Localization of $\mathrm{nAg}$ in cells through TEM. Representative TEM images show intracellular localization of $\mathrm{nAg}$ in HEK293T cells after treatment with $8 \mu \mathrm{g} / \mathrm{mL} \mathrm{nAg}$ for $24 \mathrm{~h}$. Original magnification, $\times 60000$.

$\mathrm{nAg}$, especially for $8 \mu \mathrm{g} / \mathrm{mL} \mathrm{nAg}$, relative to the untreated cells. In contrast to green color, a reduction of red fluorescence was observed for cells upon $\mathrm{nAg}$ treatment, particularly for cells treated with $8 \mu \mathrm{g} / \mathrm{mL}$ $\mathrm{nAg}$, compared to control cells (the middle panel in Figure 10A). In the merged images, we could find more striking differences between nAg-treated cells and untreated cells, with a dose-dependent drop of red fluorescence and concurrent increase of green fluoresce for nAg-treated cells, as shown in the bottom panel of Figure 10A, indicating decomposition of red fluorescent J-aggregates into green fluorescent monomer. There were no significant changes for both colors in cells upon treatment with $0.8 \mu \mathrm{g} / \mathrm{mL} \mathrm{Ag}$ ions, compared to control cells (Figure 10A). To substantiate these findings, we confirmed the increase of green fluorescence through FACS analysis. Compared to the control, a remarkable peak shift was found in $8 \mu \mathrm{g} / \mathrm{mL}$ $\mathrm{nAg}$-exposed cells relative to untreated cells $(63 \%$ vs $90 \%)$, demonstrating the increase of green fluorescent intensity (Figure 10B, $P<0.05$ ), consistent with the results obtained with confocal microscopy as described above. No significant increase in green fluorescent intensity was observed in cells treated with $\mathrm{Ag}$ ions compared to untreated cells (Figure S6). Furthermore, we quantified the fluorescent intensity of the two colors with a microplate reader. The ratio of green fluorescent intensity to red fluorescent intensity was increased in nAg-treated cells compared to untreated cells $(P<0.05)$, especially in cells treated with $8 \mu \mathrm{g} / \mathrm{mL}$ (approximately 4-fold increase) and also clearly in a dose-dependent manner from 2 to $8 \mu \mathrm{g} / \mathrm{mL}$ (Figure 10C, $P<0.05)$. An increased ratio of the green/red fluorescence intensity is diagnostic of mitochondrial depolarization. ${ }^{59,60}$ Moreover, reduction of oxidative phosphorylation could be due to suppression of the mitochondrial respiratory chain complexes. ${ }^{61-63}$ We thus evaluated the activity of succinate dehydrogenase (SDH), that is, respiratory enzyme complex II, which is the only enzyme participating in both TCA and the electron transport chain. After $24 \mathrm{~h}$ exposure, $\mathrm{nAg}$ at $4 \mu \mathrm{g} / \mathrm{mL}$ repressed SDH activity by $25 \%$, and $\mathrm{nAg}$ at $8 \mu \mathrm{g} / \mathrm{mL}$ further reduced SDH activity by more than $60 \%$, compared to that in control cells (Figure 10D, $P<0.05$ ). 

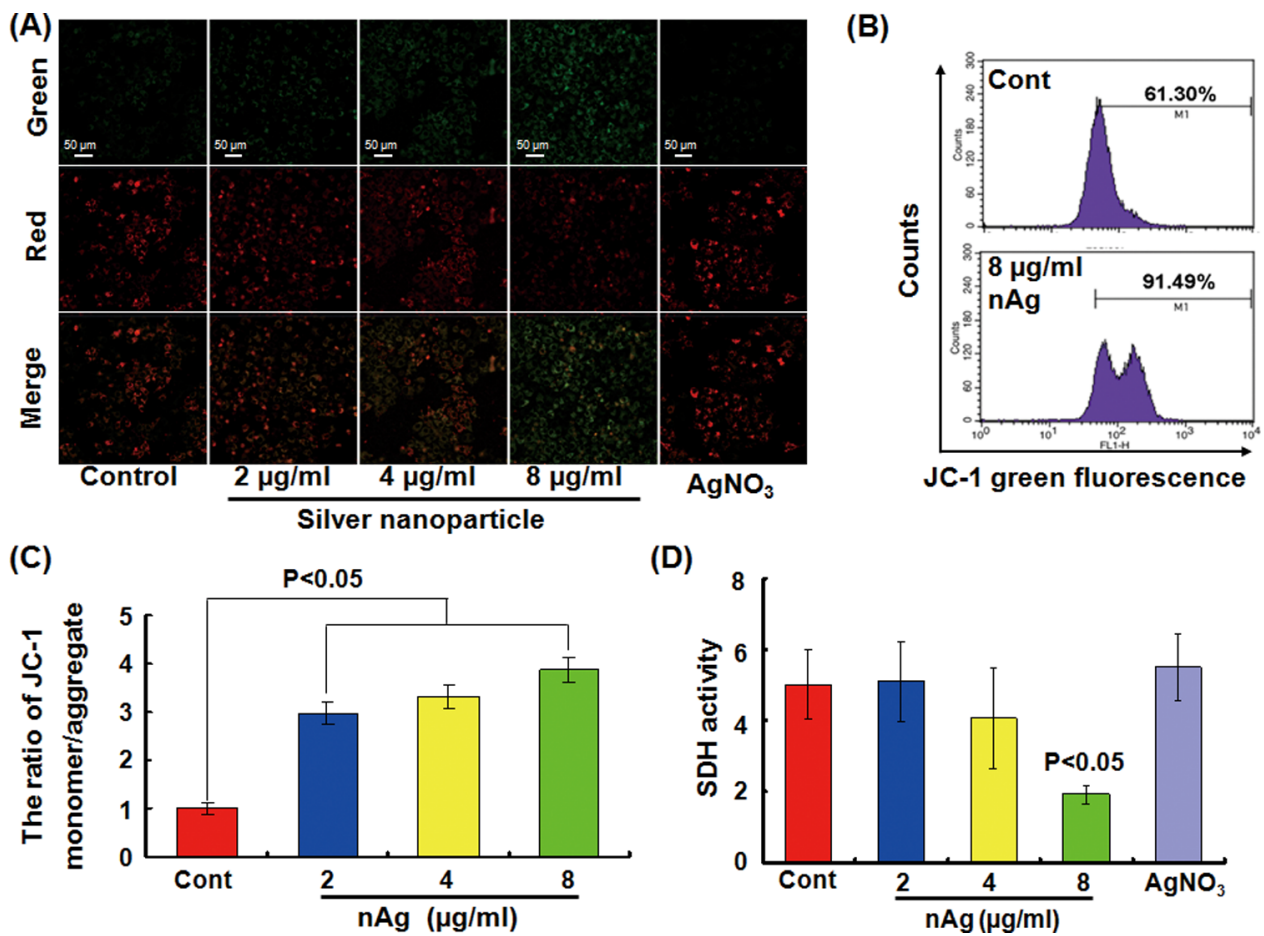

Figure 10. Mitochondrial membrane potential and SDH activity in cells upon nAg. (A) Representative images of two colors (green and red) and merged colors in cells with JC-1 staining examined by confocal microscopy. HEK293T cells were treated with $\mathrm{nAg}$ or $\mathrm{Ag}$ ions at $0.8 \mu \mathrm{g} / \mathrm{mL}$ for $24 \mathrm{~h}$ followed by staining. Original magnification, $\times 200$. (B) Flow cytometry analysis of green color after JC-1 staining in $\mathrm{nAg}$-treated cells for $24 \mathrm{~h}$. Experiments were performed in biological triplicate $(n=3)$. (C) Ratios of two colors (green/red) in cells upon $\mathrm{nAg}$ for $24 \mathrm{~h}$. Fluorescent intensity was quantified with a microplate reader $(n=6)$. (D) SDH activity was assessed in HEK293T cells upon exposure to $\mathrm{nAg}$ or $0.8 \mu \mathrm{g} / \mathrm{mL} \mathrm{AgNO}{ }_{3}$ for $24 \mathrm{~h}$. SDH activity was determined through detection of the reduction of DCPIP (2,6-dichlorophenolindophenol) dye at $600 \mathrm{~nm}$ with a microplate reader $(n=4)$.

No significant alteration in SDH activity was found in $\mathrm{AgNO}_{3}$-treated cells compared to untreated cells (Figure 10D). This observation suggested a repression of glucose metabolism through TCA and oxidative phosphorylation and also confirmed the above finding of a mode transition from aerobic to anaerobic metabolism in cells upon sublethal $\mathrm{nAg}$ exposure. Therefore, these results together demonstrated that $n A g$ greatly reduced mitochondrial membrane potential and respiratory chain complex activity.

Previous studies also suggested that $\mathrm{nAg}$ could trigger generation of intracellular ROS. ${ }^{64-66}$ In the meantime, it has been established that the mitochondrial respiratory chain itself is vulnerable to the attacks of ROS, which may oxidize sulphydryl groups of enzymes in the respiratory chain. ${ }^{6,67,68}$ In line with these reports, Hussain and colleagues revealed that $\mathrm{nAg}$ treatment weakened the activity of the mitochondrial respiratory chain by promoting ROS production in rat liver cells. ${ }^{69}$ On the basis of these findings, we hypothesized that nAg-mediated inhibition of oxidative phosphorylation could be also attributable to ROS accumulation in our study. To test this hypothesis, we assayed intracellular ROS levels in cells after nAg treatment over the time course from $30 \mathrm{~min}$ to $6 \mathrm{~h}$. Hydrogen peroxide $\left(\mathrm{H}_{2} \mathrm{O}_{2}\right)$ served as a positive control to kindle ROS production (Figure $11, P<0.05$ ). Nevertheless, no significant ROS was induced in HEK293T

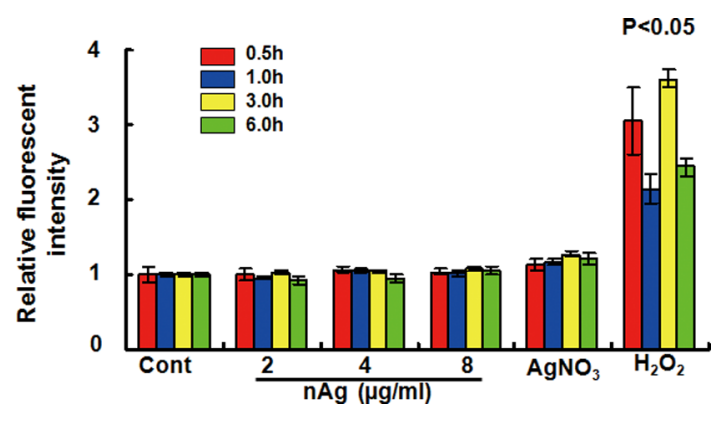

Figure 11. Intracellular ROS production upon nAg. Relative intracellular ROS production over the time course. DCF fluorescent intensities were monitored in HEK293T cells treated with various concentrations of $\mathrm{nAg}$ or $0.8 \mu \mathrm{g} / \mathrm{mL}$ Ag ions $(n=6) . \mathrm{H}_{2} \mathrm{O}_{2}$ was used as positive control.

cells treated with $\mathrm{nAg}$ at $2-8 \mu \mathrm{g} / \mathrm{mL}$ over the time course, compared to the control (Figure 11, $P>0.05$ ). In addition, there was minimal ROS induction in cells upon $\mathrm{Ag}$ ion exposure (Figure 11). To this end, we concluded that nAg-conducted inhibition of mitochondrial respiratory chain was independent of ROS production.

Our recent work demonstrated that $\mathrm{nAg}$ provides "Trojan horse" effects through which silver nanoparticles and silver ions simultaneously exist inside cells; in other words, there is a combination of $\mathrm{nAg}$ particles and $\mathrm{Ag}$ ions inside cells. ${ }^{23}$ Electrons are transferred in a finely tuned way between electron donors and 


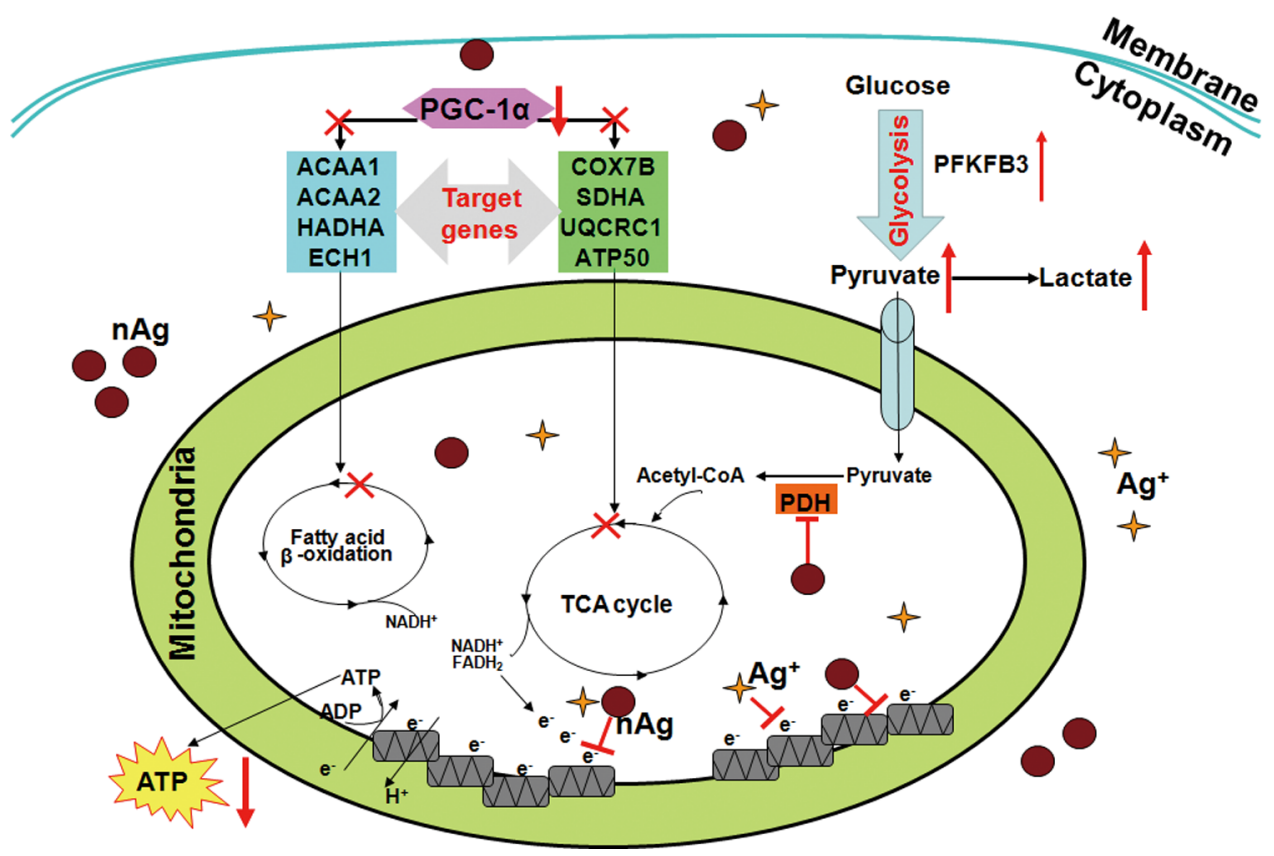

Figure 12. Schematic diagram illustrating the molecular bases underlying $\mathrm{nAg}$-conducted reprograming of energy metabolism under sublethal exposure.

electron acceptors along the respiratory chain complexes, which drives protons to move from the mitochondrial matrix into the intermembrane space and thus generates a proton gradient across the inner mitochondrial membrane, where released energy is converted into ATP. Ag ions have great capability to attract electrons, which will likely disturb electron transfer along mitochondrial respiratory chain. ${ }^{70}$ In the meantime, $\mathrm{nAg}$ particles per se may potentially perturb electron flow across the respiratory chain complexes. ${ }^{63}$ Therefore, it is possible that $\mathrm{nAg}$ particles and $\mathrm{Ag}$ ions could jointly attenuate electron transfer complexes and ATP synthesis. Although no similar finding on $\mathrm{nAg}$ has been reported before, a recent study demonstrated that graphene could disrupt electron transfer with decrease in ATP production, suggesting that this could be a potential mechanism. ${ }^{71}$

\section{CONCLUSIONS}

This study delineates the mechanisms of $\mathrm{nAg}$ induced reprogramming of energy metabolism in HEK293T cells and tumor cells with differential respiration rate (i.e., HepG2, HeLa, A498, and PC3) under sublethal concentrations. $\mathrm{nAg}$ at nontoxic concentrations incurs adaptive responses that shift from oxidative phosphorylation-based aerobic metabolism to anaerobic glycolysis to satisfy the energy demand.
Importantly, this phenomenon is independent of nAg's direct cytotoxic effects. HEK293T cells are slightly more susceptible to $\mathrm{nAg}$-induced energy mode shift than tumor cells. The detailed mechanisms responsible for these changes involve $\mathrm{nAg}$-mediated suppression of PGC- $1 \alpha$ and alterations of several energy metabolismrelated genes (including PFKFB3 and PDHA1), which force the cells to reprogram energy metabolism by switching from oxidative phosphorylation and fatty acid oxidation to glycolysis under $\mathrm{nAg}$ exposure. The subsequent energy metabolism-related gene expression changes suppress glucose metabolism (including TCA cycle and oxidative phosphorylation) and lipid metabolism (such as $\beta$-oxidation). In addition, $\mathrm{nAg}$ compromises mitochondrial membrane potential and electron transfer along the respiratory chain complexes. When mitochondrial oxidative phosphorylation is inhibited, glycolysis is switched on to compensate for the decrease in ATP production to satisfy basal energy demand for cell survival. Taken together, as illustrated in Figure 12, this study deciphers the mechanisms by which nanosilver incurs an adaptive shunt of energy metabolism mode to glycolysis in both tumor and nontumor cells under sublethal exposure. This study will shed light on our understanding on nAg's antimicrobial properties, nAg-mediated cytotoxicity, and its potential adverse health effects.

\section{MATERIALS AND METHODS}

Characterization of $\mathbf{n A g}$ Particles. $\mathrm{nAg}$ particles coated with polyvinylpyrrolidone were either purchased from Shanghai Huzheng Nanotechnology Co., Ltd., China, or nanoComposix,
Inc., USA. Stock nAg solutions were kept at $4{ }^{\circ} \mathrm{C}$ in the dark. Diluted $\mathrm{nAg}$ particles were characterized by TEM (Hitachi $\mathrm{H}-7500$, Japan). The absorption spectrum was determined with a UV-vis spectrometry (Beckman Coulter, USA). Hydrodynamic 
diameter and zeta-potential were assayed using a Zetasizer (Malvern Nano series, Malvern, UK).

Cell Culture and Mitochondria Isolation. All cell lines were purchased from the Shanghai Cell Bank of Type Culture Collection of Chinese Academy of Sciences. Human embryonic kidney cell line HEK293T, human cervical cancer cell line HeLa, human prostate cancer cell line $\mathrm{PC}$, human hepatic carcinoma cell line HepG2, and human renal carcinoma cell line A498 were routinely cultured in recommended medium (Hyclone/Gibco) supplemented with $10 \%$ FBS (Gibco) and $100 \mathrm{U} / \mathrm{mL}$ penicillinstreptomycin (Hyclone) at $37^{\circ} \mathrm{C}$ within humidified atmosphere with $5 \% \mathrm{CO}_{2}$. As to the mitochondria isolation, cells were first treated with $\mathrm{nAg}$ or $\mathrm{Ag}^{+}$, and $4.0 \times 10^{7}$ cells per sample were collected into tubes. Mitochondria were then isolated using a mitochondria isolation kit for cultured cells according to the protocol provided by the manufacturer (Abcam).

Cytotoxicity Assessment. Alamar Blue assay was carried out to examine cytotoxicity upon treatment with $\mathrm{nAg}$ and $\mathrm{AgNO}_{3}$. Cells were seeded in 96-well plates and then treated with nAg or Ag ions at different concentrations. After treatment, resazurin (Sigma) was added into complete culture media at a final concentration of $10 \%(\mathrm{v} / \mathrm{v})$, and cells were cultured for additional $2 \mathrm{~h}$. Thereafter, cells were washed with phosphatebuffered saline (PBS) three times, and fluorescence intensity measurement was subject to the detection at an excitation wavelength of $530 \mathrm{~nm}$ with an emission wavelength of $590 \mathrm{~nm}$ using a microplate reader.

Apoptosis Detection by Flow Cytometry. Cells after $\mathrm{nAg}$ or $\mathrm{Ag}$ ion treatment were collected and washed twice with PBS. Thereafter, cells were stained with $5 \mu \mathrm{L}$ of Annexin-V FITC and $5 \mu \mathrm{L}$ of $\mathrm{PI}$ for $15 \mathrm{~min}$ following the instructions form the manufacturer (BD Biosciences), followed by flow cytometry analysis as described previously. ${ }^{72}$

Real-Time RT-PCR Analysis. Total RNAs were extracted from cells post-treatment with Trizol reagent according to the manufacturer's instructions (Invitrogen). With respect to reverse transcription, $2 \mu \mathrm{g}$ of total RNAs was reverse-transcribed into CDNA with M-MLV reverse transcriptase (Promega). Gene expression levels were evaluated using SYBR Green qPCR master mix (Promega) on Mx3005P qPCR machine (Stratagene). GAPDH was used as an internal control. All primer sequences for PCR analysis are presented in Table S1.

Western Blot Analysis. Western blot analysis was carried out as previously described. ${ }^{73}$ Cells after washing with cold PBS were lysed in RIPA lysis buffer supplemented with protease inhibitor cocktail (Roche). Protein concentration was assayed with a Lowry protein concentration detection kit (Solarbio Biotechnology). The same amount of proteins for different samples were subject to $8-10 \%$ sodium dodecyl sulfate polyacrylamide gel electrophoresis (SDS-PAGE) and then transferred to nitrocellulose membranes. Antibodies were against GAPDH (1:1000, Santa Cruz Biotechnology), caspase-3 (1:500, Cell Signaling Technology), and PGC-1 $\alpha$ (1:200, Bioss).

Localization of $\mathrm{nAg}$ Inside Cells by TEM. Ultrathin sections of cells were examined by TEM to reveal localization of $\mathrm{nAg}$. Cells were treated with $8 \mu \mathrm{g} / \mathrm{mL} \mathrm{nAg}$ for $24 \mathrm{~h}$ and were washed three times with PBS. Thereafter, cells were collected and fixed in $2.5 \%$ glutaraldehyde for $2 \mathrm{~h}$, and fixed cells were washed three times with PBS. Postfixation staining was performed using $1 \%$ osmium tetroxide for $1 \mathrm{~h}$ at room temperature. Furthermore, cells were dehydrated in gradient ethanol solution and treated twice with propylene oxide for 30 min followed by treatment with propylene oxide, Spurr's low viscosity resin (1:1), for $18 \mathrm{~h}$. Cells were further treated with pure resin for $24 \mathrm{~h}$ and embedded in beem capsules containing pure resin. Resin blocks were hardened at $70^{\circ} \mathrm{C}$ for 2 days. Sections $(70 \mathrm{~nm})$ were cut and stained with $1 \%$ lead citrate and $0.5 \%$ uranyl acetate and then examined under JEOL JEM 2010F.

Measurement of Mitochondrial Membrane Potential. JC-1 dye (Invitrogen) was used to measure the membrane potential of mitochondria. Two colors were monitored at $529 \mathrm{~nm}$ for green and at $590 \mathrm{~nm}$ for red. For different purposes of detection, cells were seeded in 6-well plates or 96-well plates. After treatment for $24 \mathrm{~h}$, cells were cultured in fresh medium containing JC- 1 at final concentration of $1.5 \mu \mathrm{M}$ for $20 \mathrm{~min}$ at $37^{\circ} \mathrm{C}$. Finally, cells were washed three times and were then subjected to the analyses of confocal microscopy, flow cytometry, and microplate reader for the measurement of fluorescence intensities.

Determination of ATP Production. Cells were inoculated in 24-well plates and treated with $\mathrm{nAg}$ or Ag ions for $24 \mathrm{~h}$. Cells were then washed with cold PBS and collected into lysis buffer. The intracellular ATP levels were determined by the bioluminescent intensity using the ATP assay kit according to manufacturer's instructions (Beyotime).

Mitochondrial SDH Activity. Mitochondria were isolated from cells after treatment with $\mathrm{nAg}$ or $\mathrm{Ag}$ ions for $24 \mathrm{~h}$. SDH activity was assessed using the complex II enzyme activity microplate assay kit according to the instructions from the manufacturer (Abcam).

Intracellular ROS Level. Cells were cultured into 96-well plates and exposed to $\mathrm{nAg}$ or $\mathrm{Ag}$ ions over the time course following the protocol as described in our recent study. ${ }^{74}$ Dichlorofluorescein diacetate (DCF-DA, Sigma) was added at a final concentration of $10 \mu \mathrm{M}$ in the dark for 30 min before examination. Cells were then washed with PBS three times, and DCF fluorescence was then monitored using a microplate reader. The excitation and emission wavelength were 488 and $525 \mathrm{~nm}$, respectively, and $0.1 \% \mathrm{H}_{2} \mathrm{O}_{2}$ was used as a positive control to induce ROS in cells.

Cellular Pyruvate, Lactate, Triglyceride, and Cholesterol Concentrations. Cells were seeded in 6-well plates and were then exposed to $\mathrm{nAg}$ or $\mathrm{Ag}$ ions for $24 \mathrm{~h}$. Cells were collected and washed twice with PBS and then lysed with $1 \%$ Triton X-100 for 40 min. After centrifugation, supernatants were used for the detection of pyruvate, lactate, triglyceride, and cholesterol according to manufacturer's instructions (Jiancheng Bioengineering Institution). Protein concentrations were determined for normalization of each sample.

Quantification of Western Blot. The intensity of autoradiogram in Western blots was quantified with a software ImageJ ( $\mathrm{NIH}$, http://rsbweb.nih.gov/ij/). Specific bands were normalized to the corresponding loading control.

Statistical Analysis. Statistical analysis was performed using the SPSS 13.0 software. The difference of experimental data between two groups was assessed using independent $t$ test. The significance of mean difference among groups relative to the control was determined by one-way ANOVA test. Data were shown in mean \pm standard error. Statistical significance was determined at $P<0.05$.

Conflict of Interest: The authors declare no competing financial interest.

Acknowledgment. This work was supported by a grant under the national "973" program (Grant No. 2014CB932000), the Strategic Priority Research Program of the Chinese Academy of Sciences (Grant No. XDB14000000), and the National Natural Science Foundation of China (Grant Nos. 21377159, 21177151, 21207152). T.X. was supported by U.S. Public Health Service Grant U19 ES019528 (UCLA Center for NanoBiology and Predictive Toxicology). We thank Dr. H. Zhang for the technical assistance with TEM. We thank all the laboratory members for their great assistance with experiments and reagents.

Supporting Information Available: Additional experimental results and primer sequences related to this work are provided. This material is available free of charge via the Internet at http:// pubs.acs.org.

\section{REFERENCES AND NOTES}

1. Sintubin, L.; Verstraete, W.; Boon, N. Biologically Produced Nanosilver: Current State and Future Perspectives. Biotechnol. Bioeng. 2012, 109, 2422-2436.

2. Teow, Y.; Asharani, P. V.; Hande, M. P.; Valiyaveettil, S. Health Impact and Safety of Engineered Nanomaterials. Chem. Commun. 2011, 47, 7025-7038.

3. Morones, J. R.; Elechiguerra, J. L.; Camacho, A.; Holt, K.; Kouri, J. B.; Ramirez, J. T.; Yacaman, M. J. The Bactericidal Effect of Silver Nanoparticles. Nanotechnology 2005, 16, 2346-2353. 
4. Shahverdi, A. R.; Fakhimi, A.; Shahverdi, H. R.; Minaian, S. Synthesis and Effect of Silver Nanoparticles on the Antibacterial Activity of Different Antibiotics Against Staphylococcus aureus and Escherichia coli. Nanomedicine 2007, 3, 168-171.

5. Chaloupka, K.; Malam, Y.; Seifalian, A. M. Nanosilver as a New Generation of Nanoproduct in Biomedical Applications. Trends Biotechnol. 2010, 28, 580-588.

6. Christensen, F. M.; Johnston, H. J.; Stone, V.; Aitken, R. J.; Hankin, S.; Peters, S.; Aschberger, K. Nano-Silver: Feasibility and Challenges for Human Health Risk Assessment Based on Open Literature. Nanotoxicology 2010, 4, 284-295.

7. De Jong, W. H.; Van Der Ven, L. T.; Sleijffers, A.; Park, M. V.; Jansen, E. H.; Van Loveren, H.; Vandebriel, R. J. Systemic and Immunotoxicity of Silver Nanoparticles in an Intravenous 28 Days Repeated Dose Toxicity Study in Rats. Biomaterials 2013, 34, 8333-8343.

8. Kang, S. J.; Lee, Y. J.; Lee, E. K.; Kwak, M. K. Silver Nanoparticles-Mediated G2/M Cycle Arrest of Renal Epithelial Cells Is Associated with NRF2-GSH Signaling. Toxicol. Lett. 2012, 211, 334-341.

9. Pratsinis, A.; Hervella, P.; Leroux, J. C.; Pratsinis, S. E.; Sotiriou, G. A. Toxicity of Silver Nanoparticles in Macrophages. Small 2013, 9, 2576-2584.

10. Maraki, M.; Sidossis, L. S. Effects of Energy Balance on Postprandial Triacylglycerol Metabolism. Curr. Opin. Clin. Nutr. Metab. Care 2010, 13, 608-617.

11. O'Rahilly, S.; Farooqi, I. S. Human Obesity as a Heritable Disorder of the Central Control of Energy Balance. Int. J. Obes. 2008, 32, S55-S61.

12. O'Rahilly, S.; Farooqi, I. S. Human Obesity: A Heritable Neurobehavioral Disorder That Is Highly Sensitive to Environmental Conditions. Diabetes 2008, 57, 2905-2910.

13. Villena, J. A.; Hock, M. B.; Chang, W. Y.; Barcas, J. E.; Giguere, V.; Kralli, A. Orphan Nuclear Receptor Estrogen-Related Receptor Alpha Is Essential for Adaptive Thermogenesis. Proc. Natl. Acad. Sci. U.S.A. 2007, 104, 1418-1423.

14. Boucher, J.; Kleinridders, A.; Kahn, C. R. Insulin Receptor Signaling in Normal and Insulin-Resistant States. Cold Spring Harbor Perspect. Biol. 2014, 6, 1-23.

15. van Heerden, J. H.; Wortel, M. T.; Bruggeman, F. J.; Heijnen, J. J.; Bollen, Y. J.; Planque, R.; Hulshof, J.; O'Toole, T. G.; Wahl, S. A.; Teusink, B. Lost in Transition: Startup of Glycolysis Yields Subpopulations of Nongrowing Cells. Science 2014, 343, 1245114.

16. Friedman, J. R.; Nunnari, J. Mitochondrial Form and Function. Nature 2014, 505, 335-343.

17. Johannsen, D. L.; Ravussin, E. The Role of Mitochondria in Health and Disease. Curr. Opin. Pharmacol. 2009, 9, 780786.

18. Andon, F. T.; Fadeel, B. Programmed Cell Death: Molecular Mechanisms and Implications for Safety Assessment of Nanomaterials. Acc. Chem. Res. 2013, 46, 733-742.

19. Zhang, Y.; Yang, J. M. Altered Energy Metabolism in Cancer: A Unique Opportunity for Therapeutic Intervention. Cancer Biol. Ther. 2013, 14, 81-89.

20. Moreno-Sanchez, R.; Marin-Hernandez, A.; Saavedra, E.; Pardo, J. P.; Ralph, S. J.; Rodriguez-Enriquez, S. Who Controls the ATP Supply in Cancer Cells? Biochemistry Lessons To Understand Cancer Energy Metabolism. Int. J. Biochem. Cell Biol. 2014, 50, 10-23.

21. Simonnet, H.; Alazard, N.; Pfeiffer, K.; Gallou, C.; Beroud, C.; Demont, J.; Bouvier, R.; Schagger, H.; Godinot, C. Low Mitochondrial Respiratory Chain Content Correlates with Tumor Aggressiveness in Renal Cell Carcinoma. Carcinogenesis 2002, 23, 759-768.

22. Pelicano, H.; Xu, R. H.; Du, M.; Feng, L.; Sasaki, R.; Carew, J. S.; $\mathrm{Hu}$, Y.; Ramdas, L.; Hu, L.; Keating, M. J.; et al. Mitochondrial Respiration Defects in Cancer Cells Cause Activation of Akt Survival Pathway through a Redox-Mediated Mechanism. J. Cell Biol. 2006, 175, 913-923.

23. Wang, Z.; Liu, S.; Ma, J.; Qu, G.; Wang, X.; Yu, S.; He, J.; Liu, J.; Xia, T.; Jiang, G. B. Silver Nanoparticles Induced RNA PolymeraseSilver Binding and RNA Transcription Inhibition in Erythroid Progenitor Cells. ACS Nano 2013, 7, 4171-4186.
24. Monteiro-Riviere, N. A.; Inman, A. O.; Zhang, L. W. Limitations and Relative Utility of Screening Assays To Assess Engineered Nanoparticle Toxicity in a Human Cell Line. Toxicol. Appl. Pharmacol. 2009, 234, 222-235.

25. Horev-Azaria, L.; Baldi, G.; Beno, D.; Bonacchi, D.; Golla-Schindler, U.; Kirkpatrick, J. C.; Kolle, S.; Landsiedel, R.; Maimon, O.; Marche, P. N.; et al. Predictive Toxicology of Cobalt Ferrite Nanoparticles: Comparative In-Vitro Study of Different Cellular Models Using Methods of Knowledge Discovery from Data. Part. Fibre Toxicol. 2013, 10, 32.

26. Fabrega, J.; Luoma, S. N.; Tyler, C. R.; Galloway, T. S.; Lead, J. R. Silver Nanoparticles: Behaviour and Effects in the Aquatic Environment. Environ. Int. 2011, 37, 517-531.

27. Bar-llan, O.; Albrecht, R. M.; Fako, V. E.; Furgeson, D. Y. Toxicity Assessments of Multisized Gold and Silver Nanoparticles in Zebrafish Embryos. Small 2009, 5, 1897-1910.

28. Hengartner, M. O. The Biochemistry of Apoptosis. Nature 2000, 407, 770-776.

29. Havelaar, A. C.; de Gast, I. L.; Snijders, S.; Beerens, C. E.; Mancini, G. M.; Verheijen, F. W. Characterization of a Heavy Metal Ion Transporter in the Lysosomal Membrane. FEBS Lett. 1998, 436, 223-227.

30. Bury, N. R.; Grosell, M.; Grover, A. K.; Wood, C. M. ATPDependent Silver Transport across the Basolateral Membrane of Rainbow Trout Gills. Toxicol. Appl. Pharmacol. 1999, 159, 1-8.

31. Yu, K. N.; Yoon, T. J.; Minai-Tehrani, A.; Kim, J. E.; Park, S. J.; Jeong, M. S.; Ha, S. W.; Lee, J. K.; Kim, J. S.; Cho, M. H. Zinc Oxide Nanoparticle Induced Autophagic Cell Death and Mitochondrial Damage via Reactive Oxygen Species Generation. Toxicol. in Vitro 2013, 27, 1187-1195.

32. Bhattacharjee, S.; Rietjens, I. M.; Singh, M. P.; Atkins, T. M.; Purkait, T. K.; Xu, Z.; Regli, S.; Shukaliak, A.; Clark, R. J.; Mitchell, B. S.; et al. Cytotoxicity of Surface-Functionalized Silicon and Germanium Nanoparticles: The Dominant Role of Surface Charges. Nanoscale 2013, 5, 4870-4883.

33. Dong, X.; Mattingly, C. A.; Tseng, M. T.; Cho, M. J.; Liu, Y.; Adams, V. R.; Mumper, R. J. Doxorubicin and PaclitaxelLoaded Lipid-Based Nanoparticles Overcome Multidrug Resistance by Inhibiting P-Glycoprotein and Depleting ATP. Cancer Res. 2009, 69, 3918-3926.

34. Xu, X.; Duan, S.; Yi, F.; Ocampo, A.; Liu, G. H.; Izpisua Belmonte, J. C. Mitochondrial Regulation in Pluripotent Stem Cells. Cell Metab. 2013, 18, 325-332.

35. Asharani, P. V.; Hande, M.P.; Valiyaveettil, S. Anti-proliferative Activity of Silver Nanoparticles. BMC Cell Biol. 2009, 10, 65.

36. AshaRani, P. V.; Low Kah Mun, G.; Hande, M. P.; Valiyaveettil, S. Cytotoxicity and Genotoxicity of Silver Nanoparticles in Human Cells. ACS Nano 2009, 3, 279-290.

37. George, S.; Lin, S.; Ji, Z.; Thomas, C. R.; Li, L.; Mecklenburg, M.; Meng, H.; Wang, X.; Zhang, H.; Xia, T.; et al. Surface Defects on Plate-Shaped Silver Nanoparticles Contribute to Its Hazard Potential in a Fish Gill Cell Line and Zebrafish Embryos. ACS Nano 2012, 6, 3745-3759.

38. Wenz, T. Regulation of Mitochondrial Biogenesis and PGC-1alpha under Cellular Stress. Mitochondrion 2013, 13, 134-142.

39. Li, S.; Liu, C.; Li, N.; Hao, T.; Han, T.; Hill, D. E.; Vidal, M.; Lin, J. D. Genome-Wide Coactivation Analysis of PGC-1alpha Identifies BAF60a as a Regulator of Hepatic Lipid Metabolism. Cell Metab. 2008, 8, 105-117.

40. St-Pierre, J.; Lin, J.; Krauss, S.; Tarr, P. T.; Yang, R.; Newgard, C. B.; Spiegelman, B. M. Bioenergetic Analysis of Peroxisome Proliferator-Activated Receptor Gamma Coactivators 1alpha and 1beta (PGC-1alpha and PGC-1beta) in Muscle Cells. J. Biol. Chem. 2003, 278, 26597-26603.

41. Herzig, S.; Long, F.; Jhala, U. S.; Hedrick, S.; Quinn, R.; Bauer, A.; Rudolph, D.; Schutz, G.; Yoon, C.; Puigserver, P.; et al. CREB Regulates Hepatic Gluconeogenesis through the Coactivator PGC-1. Nature 2001, 413, 179-183.

42. St-Pierre, J.; Drori, S.; Uldry, M.; Silvaggi, J. M.; Rhee, J.; Jager, S.; Handschin, C.; Zheng, K.; Lin, J.; Yang, W.; et al. Suppression of Reactive Oxygen Species and Neurodegeneration by the PGC-1 Transcriptional Coactivators. Cell 2006, 127, 397-408. 
43. Yoon, J. C.; Puigserver, P.; Chen, G.; Donovan, J.; Wu, Z.; Rhee, J.; Adelmant, G.; Stafford, J.; Kahn, C. R.; Granner, D. K.; et al. Control of Hepatic Gluconeogenesis through the Transcriptional Coactivator PGC-1. Nature 2001, 413, 131-138.

44. Wende, A. R.; Schaeffer, P. J.; Parker, G. J.; Zechner, C.; Han, D. H.; Chen, M. M.; Hancock, C. R.; Lehman, J. J.; Huss, J. M.; McClain, D. A.; et al. A Role for the Transcriptional Coactivator PGC-1alpha in Muscle Refueling. J. Biol. Chem. 2007, 282, 36642-36651.

45. Zhao, C.; Dahlman-Wright, K.; Liver, X. Receptor in Cholesterol Metabolism. J. Endocrinol. 2010, 204, 233-240.

46. Oberkofler, H.; Schraml, E.; Krempler, F.; Patsch, W. Potentiation of Liver $\mathrm{X}$ Receptor Transcriptional Activity by Peroxisome-Proliferator-Activated Receptor gamma Coactivator 1alpha. Biochem. J. 2003, 371, 89-96.

47. Shin, D. J.; Campos, J. A.; Gil, G.; Osborne, T. F. PGC-1alpha Activates CYP7A1 and Bile Acid Biosynthesis. J. Biol. Chem. 2003, 278, 50047-50052.

48. Yalcin, A.; Telang, S.; Clem, B.; Chesney, J. Regulation of Glucose Metabolism by 6-Phosphofructo-2-Kinase/ Fructose-2,6-Bisphosphatases in Cancer. Exp. Mol. Pathol. 2009, 86, 174-179.

49. Rodriguez-Rodriguez, P.; Almeida, A.; Bolanos, J. P. Brain Energy Metabolism in Glutamate-Receptor Activation and Excitotoxicity: Role for APC/C-Cdh1 in the Balance Glycolysis/Pentose Phosphate Pathway. Neurochem. Int. 2013, 62, 750-756.

50. Roche, T. E.; Hiromasa, Y. Pyruvate Dehydrogenase Kinase Regulatory Mechanisms and Inhibition in Treating Diabetes, Heart Ischemia, and Cancer. Cell. Mol. Life Sci. 2007, 64, 830-849.

51. Amoroso, F.; Falzoni, S.; Adinolfi, E.; Ferrari, D.; Di Virgilio, F. The P2X7 Receptor Is a Key Modulator of Aerobic Glycolysis. Cell Death Dis. 2012, 3, e370.

52. Kamarajugadda, S.; Stemboroski, L.; Cai, Q.; Simpson, N. E.; Nayak, S.; Tan, M.; Lu, J. Glucose Oxidation Modulates Anoikis and Tumor Metastasis. Mol. Cell. Biol. 2012, 32, 1893-1907.

53. Hitosugi, T.; Fan, J.; Chung, T. W.; Lythgoe, K.; Wang, X.; Xie, J.; Ge, Q.; Gu, T. L.; Polakiewicz, R. D.; Roesel, J. L.; et al. Tyrosine Phosphorylation of Mitochondrial Pyruvate Dehydrogenase Kinase 1 Is Important for Cancer Metabolism. Mol. Cell 2011, 44, 864-877.

54. Wei, L.; Tang, J.; Zhang, Z.; Chen, Y.; Zhou, G.; Xi, T. Investigation of the Cytotoxicity Mechanism of Silver Nanoparticles in Vitro. Biomed. Mater. 2010, 5, 044103.

55. Bressan, E.; Ferroni, L.; Gardin, C.; Rigo, C.; Stocchero, M.; Vindigni, V.; Cairns, W.; Zavan, B. Silver Nanoparticles and Mitochondrial Interaction. Int. J. Dent. 2013, 2013, 312747.

56. Smiley, S. T.; Reers, M.; Mottola-Hartshorn, C.; Lin, M.; Chen, A.; Smith, T. W.; Steele, G. D., Jr.; Chen, L. B. Intracellular Heterogeneity in Mitochondrial Membrane Potentials Revealed by a J-Aggregate-Forming Lipophilic Cation JC-1. Proc. Natl. Acad. Sci. U.S.A. 1991, 88, 3671-3675.

57. Reers, M.; Smith, T. W.; Chen, L. B. J-aggregate Formation of a Carbocyanine as a Quantitative Fluorescent Indicator of Membrane Potential. Biochemistry 1991, 30, 4480-4486.

58. Cossarizza, A.; Baccarani-Contri, M.; Kalashnikova, G.; Franceschi, C. A New Method for the Cytofluorimetric Analysis of Mitochondrial Membrane Potential Using the J-Aggregate Forming Lipophilic Cation 5,5',6,6'-Tetrachloro$1,1^{\prime}, 3,3^{\prime}$-Tetraethylbenzimidazolcarbocyanine lodide (JC-1). Biochem. Biophys. Res. Commun. 1993, 197, 40-45.

59. Kang, M. H.; Kang, Y. H.; Szymanska, B.; Wilczynska-Kalak, U.; Sheard, M. A.; Harned, T. M.; Lock, R. B.; Reynolds, C. P. Activity of Vincristine, L-ASP, and Dexamethasone against Acute Lymphoblastic Leukemia Is Enhanced by the BH3Mimetic ABT-737 in Vitro and in Vivo. Blood 2007, 110, 2057-2066.

60. Dorrie, J.; Gerauer, H.; Wachter, Y.; Zunino, S. J. Resveratrol Induces Extensive Apoptosis by Depolarizing Mitochondrial Membranes and Activating Caspase- 9 in Acute Lymphoblastic Leukemia Cells. Cancer Res. 2001, 61, 47314739.
61. Baratli, Y.; Charles, A. L.; Wolff, V.; Ben Tahar, L.; Smiri, L.; Bouitbir, J.; Zoll, J.; Piquard, F.; Tebourbi, O.; Sakly, M.; et al. Impact of Iron Oxide Nanoparticles on Brain, Heart, Lung, Liver and Kidneys Mitochondrial Respiratory Chain Complexes Activities and Coupling. Toxicol. in Vitro 2013, 27, 2142-2148.

62. Teodoro, J. S.; Simoes, A. M.; Duarte, F. V.; Rolo, A. P.; Murdoch, R. C.; Hussain, S. M.; Palmeira, C. M. Assessment of the Toxicity of Silver Nanoparticles in Vitro: A Mitochondrial Perspective. Toxicol. in Vitro 2011, 25, 664-670.

63. Costa, C. S.; Ronconi, J. V.; Daufenbach, J. F.; Goncalves, C. L.; Rezin, G. T.; Streck, E. L.; Paula, M. M. In Vitro Effects of Silver Nanoparticles on the Mitochondrial Respiratory Chain. Mol. Cell. Biochem. 2010, 342, 51-56.

64. Carlson, C.; Hussain, S. M.; Schrand, A. M.; Braydich-Stolle, L. K.; Hess, K. L.; Jones, R. L.; Schlager, J. J. Unique Cellular Interaction of Silver Nanoparticles: Size-Dependent Generation of Reactive Oxygen Species. J. Phys. Chem. B 2008, 112, 13608-13619.

65. Kim, S.; Choi, J. E.; Choi, J.; Chung, K. H.; Park, K.; Yi, J.; Ryu, D. Y. Oxidative Stress-Dependent Toxicity of Silver Nanoparticles in Human Hepatoma Cells. Toxicol. in Vitro 2009, 23, 1076-1084.

66. Foldbjerg, R.; Olesen, P.; Hougaard, M.; Dang, D. A.; Hoffmann, H. J.; Autrup, H. PVP-Coated Silver Nanoparticles and Silver lons Induce Reactive Oxygen Species, Apoptosis and Necrosis in THP-1 Monocytes. Toxicol. Lett. 2009, 190, $156-162$.

67. Adam-Vizi, V. Production of Reactive Oxygen Species in Brain Mitochondria: Contribution by Electron Transport Chain and Non-electron Transport Chain Sources. Antioxid Redox Signaling 2005, 7, 1140-1149.

68. Navarro, A.; Boveris, A. The Mitochondrial Energy Transduction System and the Aging Process. Am. J. Physiol. Cell. Physiol. 2007, 292, C670-C686.

69. Hussain, S. M. Hess, K. L.; Gearhart, J. M.; Geiss, K. T. Schlager, J. J. In Vitro Toxicity of Nanoparticles in BRL 3A Rat Liver Cells. Toxicol. in Vitro 2005, 19, 975-983.

70. Miyayama, T.; Arai, Y.; Suzuki, N.; Hirano, S. Mitochondrial Electron Transport Is Inhibited by Disappearance of Metallothionein in Human Bronchial Epithelial Cells Following Exposure to Silver Nitrate. Toxicology 2013, 305, 20-29.

71. Zhou, H.; Zhang, B.; Zheng, J.; Yu, M.; Zhou, T.; Zhao, K.; Jia, Y.; Gao, X.; Chen, C.; Wei, T. The Inhibition of Migration and Invasion of Cancer Cells by Graphene via the Impairment of Mitochondrial Respiration. Biomaterials 2014, 35, 15971607.

72. Liu, S.; Li, S.; Du, Y. Polychlorinated Biphenyls (PCBs) Enhance Metastatic Properties of Breast Cancer Cells by Activating Rho-Associated Kinase (ROCK). PLoS One 2010, 5, e11272.

73. Liu, S.; Goldstein, R. H.; Scepansky, E. M.; Rosenblatt, M. Inhibition of Rho-Associated Kinase Signaling Prevents Breast Cancer Metastasis to Human Bone. Cancer Res. 2009, 69, 8742-8751.

74. Qu, G.; Liu, S.; Zhang, S.; Wang, L.; Wang, X.; Sun, B.; Yin, N.; Gao, X.; Xia, T.; Chen, J. J.; et al. Graphene Oxide Induces Toll-like Receptor 4 (TLR4)-Dependent Necrosis in Macrophages. ACS Nano 2013, 7, 5732-5745. 